Check for updates

Cite this: Sens. Diagn., 2022, 1, 87

\title{
Recent developments towards portable point-of- care diagnostic devices for pathogen detection
}

\author{
Sharmili Roy, (D) $\dagger^{\mathrm{ab}}$ Fareeha Arshad, (D) $\dagger^{\mathrm{ac}}$ Shimaa Eissa, (D) ${ }^{\mathrm{d}}$ Mohammadali Safavieh, (D) \\ Sanaa G. Alattas, (D) ${ }^{f}$ Minhaz Uddin Ahmed (D) ${ }^{* a}$ and Mohammed Zourob (iD)*cg
}

\begin{abstract}
The rapid development of accurate and quick diagnostic tools for infectious diseases has made a massive impact in global health. POC devices for pathogen detection have primarily contributed to clinical management in various applications such as pathology, drug discovery and food safety. Diagnostic tests in isolated or remote areas were previously time-consuming, costly, and the methods were extensive and laborious. However, the new generation of miniaturized biosensor technologies aimed at POC testing resulted in a more sensitive, reliable, rapid and cost-effective detection process without needing sophisticated instruments. Among them, a few were developed as ready-to-use devices and are currently commercially available. In this review, we presented the most recent developments in diagnostic methods in pathogen detection and the improvements included in the detection steps in recent POCs for pathogen detection. We also discussed incorporating nanomaterials, microfluidics, lateral flow tests, screen-printed electrodes and smartphones into POC devices used in this area. The challenges and prospects of developing sample-to-results POC devices for pathogen detection were also discussed.
\end{abstract}

Received 4th September 2021, Accepted 27th October 2021

DOI: $10.1039 / \mathrm{d} 1 \mathrm{sd} 00017 \mathrm{a}$

rsc.li/sensors samples, to decrease the medical expenses, experimental steps, and analytical time. ${ }^{1}$ There is a continuous need to develop "sample-to-results" POC devices for on-site monitoring in rural/isolated areas to be operated by semiskilled personnel for rapid quantification of analytes. This will enable better monitoring towards infection outbreaks and treatment of diseases. Fig. 1 is a schematic overview of POC applications that have been developed by researchers, and among them, few devices are already available in the market to use.

In the last decade, numerous techniques have been developed for the purpose of pathogen detection (Fig. 1), but only a few made it to the market for real-life applications. This review focused on POC devices that have been commercially developed for pathogen detection, with stronger emphasis on profiling the underlying technologies available for the development of POC devices in this area, as

\footnotetext{
${ }^{a}$ Biosensors and Nanobiotechnology Laboratory, Chemical Science Programme, Faculty of Science, Universiti Brunei Darussalam, Jalan Tungku Link, Gadong, BE 1410, Brunei Darussalam.E-mail: minhaz.ahmed@ubd.edu.bn

${ }^{b}$ School of Medicine, Stanford University, Stanford, California 94305, USA

${ }^{c}$ Aligarh Muslim University 202002 Aligarh, Uttar Pradesh, India

${ }^{d}$ Department of Chemistry, Alfaisal University, Al Zahrawi Street, Al Maather, Al Takhassusi Road, Riyadh 11533, Kingdom of Saudi Arabia

${ }^{e}$ Division of Biomedical Engineering, Division of Renal Medicine, Department of Medicine, Brigham and Women's Hospital, Harvard Medical School, Cambridge, MA 02139, USA

${ }^{f}$ Department of Biological Sciences, Faculty of Science, King Abdulaziz University, P.O. Box 4702, Jeddah 21412, Kingdom of Saudi Arabia

${ }^{g}$ King Faisal Specialist Hospital and Research Center, Zahrawi Street, Al Maather, Riyadh 12713, Saudi Arabia. E-mail: mzourob@alfaisal.edu

$\dagger$ Sharmili Roy and Fareeha Arshad contributed equally to this manuscript.
} well as their limitations.

\section{Methods for the detection and identification of pathogens}

\subsection{Conventional culture-based method}

Microbial culture has been the gold-standard for identification of microbes present in clinical samples for decades. Naturally, the growth medium is composed of essential supplements that will support and promote the growth of microorganisms. For the purpose of further 

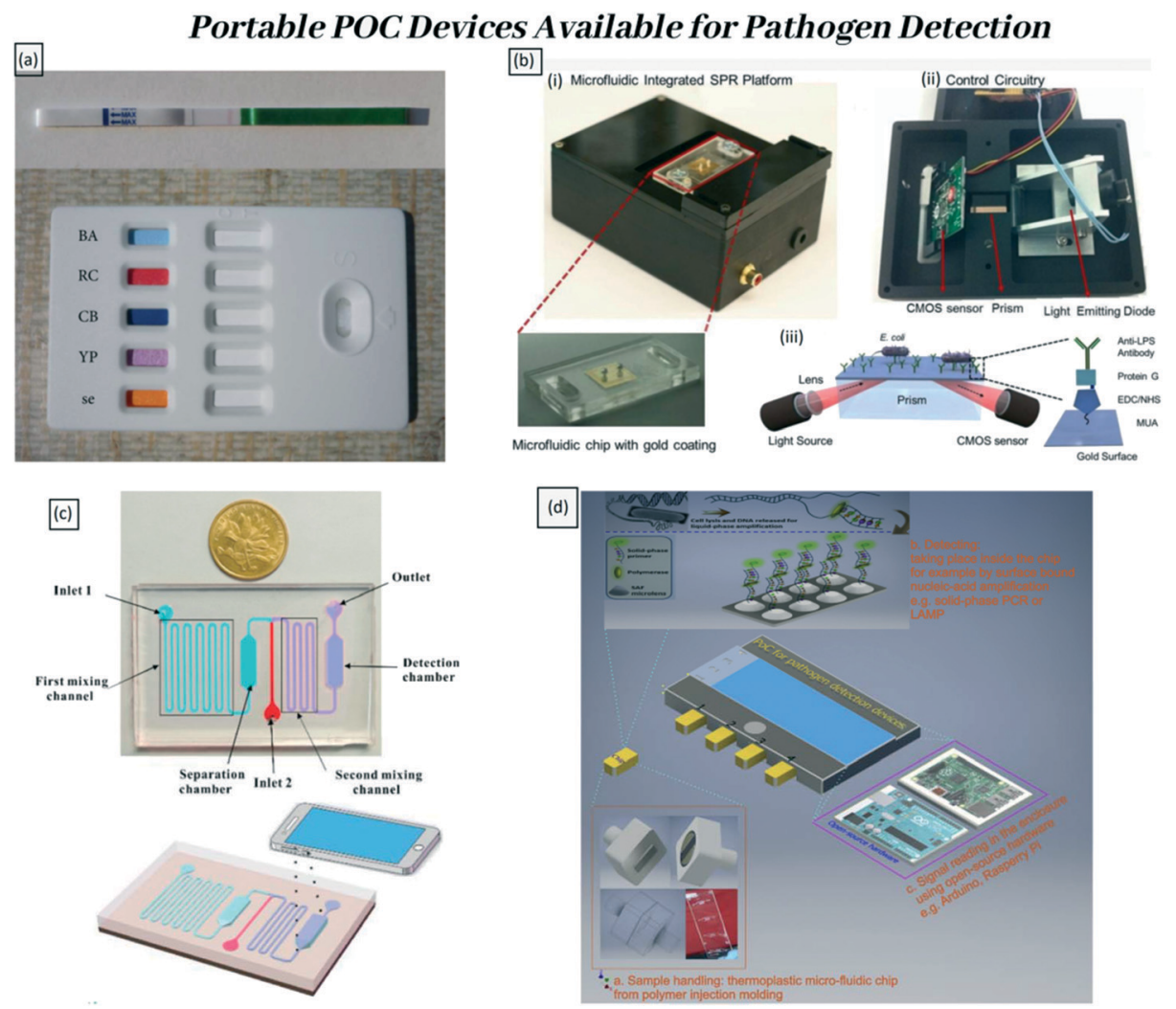

Fig. 1 Examples of portable POC devices available for pathogen detection. (a) Appearance of a commercial LFT device that can detect five biological warfare agents Bacillus anthracis, ricin, Clostridium botulinum/botulinum toxin, Yersinia pestis, and staphylococcal enterotoxin B by Pro Strips (Advnt Biotechnologies, Phoenix, AZ, USA). Adapted with permission from ref. 2, copyright@2021 (Hindawi). (b) Portable plasmonic platform for pathogen detection and quantification. (i) The surface activated disposable microfluidic chips mounted on the device. (ii) The electronic setup of the device is represented from the bottom. (iii) Schematics of the microfluidic integrated SPR platform. The gold surfaces were modified with several activators that can capture E. coli. Adapted with permission from ref. 3, copyright@2015 (Nature). (c) The principle of the proposed colorimetric biosensor for rapid detection of Escherichia coli O157:H7 based on gold nanoparticle aggregation and smart phone imaging. Adapted with permission from ref. 4, copyright@2019 (Elsevier). (d) The three essential components of POC devices for (multiplex) pathogen detection and the proposed solutions. Adapted with permission from ref. 5, copyright@2020 (Elsevier).

isolation, the growth media are mixed with specific antibiotics, such as ampicillin, kanamycin and tetracycline, to prevent contamination by other microbes on the agar plate. ${ }^{6}$ This is a basic tool employed worldwide due to its apparent reliability, efficiency and sensitivity. However, this traditional method is very tedious, consisting of many steps, such as sample preparation from food samples, preenrichment, enrichment, plating, colony selection and further confirmation via biochemical screening such as morphology observation, staining and biochemical testing. ${ }^{7}$ Although the method is relatively inexpensive and simple, it is laborious and time-consuming as aseptic techniques were to be followed thoroughly. The identification process could take anywhere between 2 and 10 days and requires trained lab personnel to prepare the samples, perform the tests and interpret the results. Moreover, it is only effective in identifying a fraction of microbes in a given sample, and is incapable of providing accurate microbial virulence factors. In addition, it is not suitable for applications requiring immediate results, in particular, during an outbreak in the food and water industries.

\subsection{Nucleic acid-based PCR method}

In comparison to the above-mentioned conventional method, the analysis time and cost of running DNA-based microbial identification methods are significantly less, while providing similarly robust and conclusive results. The first-ever DNAbased diagnostic method introduced was the polymerase chain reaction (PCR) technique, developed by Kary Mullis in the 1980s. ${ }^{8}$ The method isolates, amplifies and quantifies a short DNA sequence on the target bacteria's genetic material from a complex pool of DNA using a specifically designed pair of primers and DNA polymerase as an enzyme. The amplified sequence is later detected using gel electrophoresis. Based on the PCR principle, many advanced nucleic acid amplification techniques were developed such as reverse transcription PCR $(\mathrm{RT}-\mathrm{PCR})^{9}$ and real-time quantitative PCR (qPCR). ${ }^{10}$ PCR-based detection procedures are rapid, taking anywhere between 5 and 24 hours to obtain results (excluding the enrichment stage), depending on which type of PCR is performed. ${ }^{11}$ The method is highly specific and sensitive, needing a smaller reagent volume and 
utilizing instruments that are easily available. This assay has been widely used for pathogen detection from various types of samples, from processed food samples to faecal samples from various living organisms. In the recent COVID-19 pandemic, the causative pathogen SARS-CoV-2 coronavirus has been widely detected using RT-PCR and qRT-PCR worldwide. ${ }^{12-15}$ The technique is used to quantify the viral load in both symptomatic and asymptomatic patients with very good specificity and sensitivity. Globally, 104 PCR kits are in use to detect this pathogen in hospitals, medical centres, university campuses and airports. ${ }^{15-17}$ However, usage of a thermal cycler, low sensitivity issues, contamination or carry over issues and false positive issues are some of the disadvantages of this method. Hence, the development of other advanced methods is in demand to detect pathogens.

\subsection{Antigen-antibody-based (ELISA) method}

After the PCR method, another popular way to detect pathogens is by employing the immunological-based technique called enzyme-linked immunosorbent assay (ELISA). The basic concept of ELISA is based on antibodyantigen interactions, whereby a particular antibody will bind to its specific antigen. The strength of 'antibody binding' determines the sensitivity and specificity of the method. In general, an antigen (for example, a bacterial cell or bacterial toxin) is immobilized onto a solid surface to capture the antibody. If there is interaction between the antigen and the antibody, then this is detected by the addition of a substrate that can generate a colour change or fluorescence. Three types of ELISA have been extensively used, which are 1) direct ELISA, 2) indirect ELISA and 3) sandwich ELISA. ${ }^{18}$ Sandwich ELISA has been previously utilized for the detection of Vibrio parahaemolyticus in seafood, ${ }^{19}$ with availability of commercial ELISA kits for detection of pathogens in food products, like Salmonella species. $^{20}$ The ELISA method gives the final readout in a relatively short period of time. However, since it is a single end-point assay, there is a high possibility of obtaining false positive or negative outcomes. Moreover, this technique is considered to be relatively expensive due to the high cost of instruments and reagents needed. The antibody needed in this technique is relatively unstable. Additionally, antibody production is a laborious and costly process. At the same time, it is also challenging to adapt the method for high-throughput screening processes on a larger scale. ${ }^{21,22}$

\subsection{Micro-array-based method}

On the other hand, a DNA microarray can perform simultaneous detection of many pathogens at one time that is achievable through miniaturization. In this process, glass slides are coated with hundreds of specific short oligonucleotide probes that are able to target a part of the gene sequence derived from pathogens. ${ }^{23}$ Due to the small volume size of the reactions, this method is able to achieve a low limit of detection (LOD) and low running cost. Overall, it enables relatively faster detection of pathogens due to reduction in sample preparation time and incorporation of microfluidics technology. ${ }^{24}$ Pathogen detection using the DNA microarray was previously employed for only viral and fungal infection screening processes. ${ }^{25,26}$ Recently, a PCRbased microarray assay was reported to achieve good sensitivity by Vora and colleagues in the detection of Escherichia coli $(\mathrm{O} 157: \mathrm{H} 7)$ from water samples. The LOD achieved was 100 genomic copies per reaction with a specificity of $97 \% .^{27}$ Thus, this method has big potential in environmental surveillance of pathogen identification.

\subsection{Biosensor-based method}

A biosensor is a device that contains a bioreceptor and a transducer that can recognize the target analyte derived from pathogens. Essentially, the bioreceptor recognizes the biological event taking place and the transducer converts the biological reaction into a measurable signal..$^{28-30}$ Biosensors have been increasingly utilized in foodborne and waterborne pathogen detection in order to address one of the main challenges in the area, which is the rapid detection of a small amount of microorganisms, as they help to detect a tiny amount of antigen with high accuracy and rapidity. Some examples of pathogens that could be identified using various biosensors are E. coli, L. monocytogenes and Salmonella. ${ }^{31,32}$ Additionally, biosensor technologies have been the preferred method for pathogen detection recently as most of the systems are automated with a simple operation procedure, portable, and inexpensive and, most importantly, this area has been increasingly adapted as POC devices. Moreover, the integration of micro- and nano-fabrication technologies into the biosensor platform can enable screening of multiple pathogens in a single device. Increasingly, nanomaterials (NMs), such as nanoparticles, nanosheets, nanotubes, nanowires and nanorods, have been incorporated into biosensor platforms for pathogen detection to increase sensitivity and specificity. ${ }^{33}$

\subsection{Isothermal-based DNA amplification method}

As an alternative to PCR-based nucleic acid detection, the molecular biology field has developed various techniques that can amplify DNA isothermally in a single heat block. This means that amplification is performed at a constant temperature, reducing the need for an expensive thermal cycler and skilled personnel as well as shortening the reaction time. Some of the isothermal amplification methods that have been introduced are loop-mediated isothermal amplification (LAMP), ${ }^{34-36}$ helicase-dependent amplification (HAD), ${ }^{37}$ isothermal strand displacement amplification $(\mathrm{SDA}){ }^{38}$ rolling circle amplification (RCA) ${ }^{39}$ and signalmediated amplification of RNA technology (SMART). ${ }^{40}$ Among all these techniques, LAMP appeared to be popular for pathogen detection as it is capable of amplifying medium to long ranges of targeted nucleic acid strands with high efficiency, sensitivity, specificity and stability. ${ }^{41-44}$ The 
combination of LAMP in biosensors allowed for a straightforward detection of pathogens using a paper-based colorimetry assay, and this approach could be useful as POC devices. ${ }^{45}$ One of the recent studies was conducted on the fish pathogen Streptococcus iniae with a colorimetric biosensor using gold nanoparticle-labelled probes and LAMP assay. In this study, the authors were able to detect a LOD of $10^{2}$ CFU which is more sensitive than normal PCR and the conventional lateral flow strip process. Additionally, the whole process of detection took place less than 2 h. ${ }^{39}$ Many researchers have combined the LAMP method with an electrochemical sensor (E-Sensor) to achieve better sensitivity and good reproducibility. It has been proven that this E-sensor has the capability of detecting pathogens in a broad detection range like $1 \mathrm{fg} \mu \mathrm{L}^{-1}$ to $100 \mathrm{pg} \mu \mathrm{L}^{-1}$. ${ }^{46}$ However, the LAMP-based sensor also has some drawbacks such as long collection time, deep data analysis, some safety concerns, and the primer design is complicated. ${ }^{47,48}$

\section{Enhancements in current POC devices for pathogen detection}

\subsection{Sample preparation}

Sample processing is a crucial prerequisite step in pathogen detection, and it is required to concentrate raw samples from liters $(\mathrm{L})$ down the microliter $(\mu \mathrm{L})$ scale, which is a volume that is more suitable for processing by POC detection strategies. For most occasions, the collection of a relatively large raw sample volume which is mixed with other impurities or untargeted elements is required to increase the likelihood of detecting pathogens, which are often present at very low concentrations. Preparation of samples for any sensor-based detection process requires minute observation specially to make the sample pure from unwanted elements that come with the collected raw samples. In a nucleic acidbased sensor, first DNA is extracted with an available extraction kit and then prepared for further analysis using a sensor. $^{49-51}$

The presence of inhibitors, interference of mix elements, and relatively low microbial cell numbers in a sample to be analyzed can be problematic for minute detection analysis. The presence of these substances in abundance reduces the overall selectivity of the sensor and creates cross contamination issues. Thus, solving the selectivity issue is one of the significant challenges in developing practical biosensors. The basic strategies that allow selective detection using biosensors include having a clear idea of the sample composition, designing the biosensor such that the possible interferences are taken into consideration, and rechecking the method against a standard procedure. More importantly, the sample must be optimized in such a way that they are devoid of any interfering compounds during the detection. This issue can be tackled by having pre-treatments on samples such as separation and concentration of pathogen target analytes from various sample matrices. Sample pretreatments are generally very difficult and take up the most out of the assay time. Conventional sample preparation for pathogen detection requires tedious procedures. For instance, the procedures involved in this case are inoculation and selective culturing of microorganisms, physical lysis to release the cell contents, sub-cloning or cloning into appropriate hosts, purifications and so on before the presence of target analytes can be tested on desired detection platforms.

\subsection{Bio-recognition receptors}

To tackle the limitations posed by antibodies, alternative molecules have been studied. Aptamers, artificial binding proteins, molecularly imprinted polymers, and NPs can selectively bind to biomolecules. ${ }^{52}$ In this review, we described antibodies, bacteriophages, and aptamers in detail. These antibody alternatives do not use animal hosts for antibody production and therefore do not pose any ethical issue for the public and scientific community. ${ }^{53,54}$

3.2.1. Antibodies. For decades, antibodies have been primarily used as recognition probes in detecting and diagnosing pathogenic microorganisms. The immune system produces antibodies to defend the body against any foreign antigen exposure. In scientific studies, antibodies are harvested in mammals by immunizing them with specific antigens. Because of their highly precise binding capability, antibodies are employed as recognition probes in detection bioassays. Sandwich-type assays are the best to illustrate the significant roles of antibodies in detection bioassays. In sandwich-type immunoassays, there are at least two antibodies: one plays the role of the recognition probe and the other acts as the signalling probe. The success of the immunoassay relies predominantly on the specificity and sensitivity of the recognition antibody's binding ability with the target of interest. This approach has been applied for the detection of Escherichia coli ${ }^{55-57}$ Mycobacterium tuberculosis, ${ }^{58}$ influenza viruses, ${ }^{59} \mathrm{HIV},{ }^{60,61}$ Staphylococcus aureus, ${ }^{62,63}$ Salmonella species, ${ }^{57,64,65}$ Listeria species, ${ }^{66,67}$ Shigella species, ${ }^{68,69}$ Norovirus strains ${ }^{70,71}$ and Clostridium species. ${ }^{72,73}$

Full-length antibodies have two unique polypeptides such as the light and heavy chains. The antigen-restricting site is shaped by six hyper-variable circles, three each from the two chains. Because of the complex engineering involved, the cloning steps for the recombinant expression of a full-length immune response can become complicated. Besides, the fundamental multifaceted nature of full-length antibodies requires a customary articulation framework for the mass generation of full-length antibodies. To overcome this restriction, counteracting agents like substantial chain antibodies have been developed. These neutralizer parts cannot hold the complete antigen and, therefore, restrict a full-length immune response. This makes the process less demanding in terms of development and control.

3.2.2. Bacteriophages. Bacteriophages infect bacterial cells and are abundantly found in nature. There are about $10^{32}$ bacteriophage entities in soil, manure, thermal vents, and 
water. Apart from their abundance, their ability to survive adverse environmental conditions and reproduce quickly in their specific targeted host makes them ideal regulators of microbial balance on earth and an indicator of dynamic equilibrium amongst bacterial species. ${ }^{74}$ Phages offer many advantages in biosensing, like the specificity in binding to their target host cells, the ability to lyse and kill their hosts, and the capacity to multiply during an infection process. This makes phages a valuable tool for the detection and identification of bacterial pathogens.

Bacteriophages have been employed in different ELISA formats as recognition molecules to capture analytes. For instance, $\beta$-galactosidase, streptavidin, and neutravidin molecules are used in the direct ELISA format. This was seen in the study carried out by Rajkovic and colleagues, where a landscape phage library was used to select target-specific phage particles. ${ }^{75}$ Bacillus anthracis spores were captured by spore binding phages selected from the f8/8 landscape phage library. A phage like M13 was used as a reporter to identify the captured molecules. This event was amplified using antiM13 horseradish peroxidase (HRP) that binds to each pVIII protein. This approach was successfully used to detect Brucella melitensis. The cells were captured using purified single chain antibodies (scAb) on the HRP conjugated phage that displayed antibody fragments $(\mathrm{scFv})$ in the sandwich ELISA format. This resulted in two orders of magnitude improvement in sensitivity compared to the soluble format. ${ }^{76}$ In a similar approach, phage-displayed single domain antibodies (sdAb) were used as reporter elements to detect several analytes, including ricin, botulinum-A toxin complex, and Marburg virus in the sandwich ELISA format. The sensitivity of assays was seen to be improved compared to the soluble sdAb. ${ }^{77-79}$

During the past decade, several bacterial analytes have been detected by SPR biosensors that employ a phage as the bio-recognition probe. Likewise, a lytic phage was used in the SPREETA $^{\mathrm{TM}}$ sensor to detect Staphylococcus aureus and

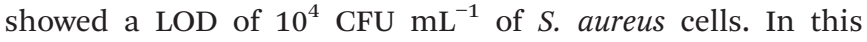
study, it was observed that the nonspecific Salmonella typhimurium did not create any significant response. At the same time, E. coli detection was performed using a T4 phage probe in the SPR imaging system with a LOD of $10^{4} \mathrm{CFU}$ $\mathrm{mL}^{-1} \cdot{ }^{80}$ A Salmonella-specific M13 phage selected from a commercially available phage display peptide library was employed to detect Salmonella cells with a LOD of $1.3 \times 10^{7}$ CFU $\mathrm{mL}^{-1}$. A similar approach was employed to detect $\beta$-galactosidase ( $\beta$-gal), a well-known coliform marker used by the SPREETA ${ }^{\mathrm{TM}}$ sensor. It helped to achieve a linear range of $10^{-9}-10^{-6} \mathrm{M}$. SPR sensors successfully detected $E$. coli bacteria using a T4 phage where the bacterial cells were detected in a concentration range of $7 \times 10^{2}$ to $7 \times 10^{8} \mathrm{CFU} \mathrm{mL}{ }^{-1} \cdot{ }^{81} \mathrm{In}$ another study carried out by Tawil and co-workers, T4 and BP14 phages were employed in a phase-sensitive SPR to detect E. coli and methicillin-resistant Staphylococcus aureus (MRSA) with a LOD of $10^{3} \mathrm{CFU} \mathrm{mL}^{-1}$ for both species. ${ }^{82}$ At the same time, another group employed the T4 phage by physical adsorption on long-period fibre gratings (LPGs) to detect $E$. coli in their studies. ${ }^{83}$ The LPG sensing principle relies on measuring the changes in resonance wavelength $\left(\lambda_{\mathrm{R}}\right)$ due to the external refractive index changes. Additionally, a modified, more accurate and extremely sensitive version of the LPG sensing platform was developed by the same group that used telecommunication wavelengths ( $1.56 \mathrm{um})$. This sensor was shown to have improved the LOD down to $10^{3}$ CFU $\mathrm{mL}^{-1}$ and achieved a linear range of $10^{3}-10^{6} \mathrm{CFU} \mathrm{mL}^{-1}$ for $E$. coli detection. ${ }^{84}$ Furthermore, an evanescent mode of a terahertz fibre was recently used by Mazhorova et al. to detect E. coli bacteria using T4 phages. ${ }^{85}$ The system achieved a LOD of $10^{3} \mathrm{CFU} \mathrm{mL} \mathrm{m}^{-1}$ E. coli bacteria.

Electrochemical biosensors (EB) have received significant attention in the biosensing field due to their low cost, simplicity, portability, high accuracy, and sensitivity. ${ }^{86}$ Phage particles are utilized as recognition receptors in these devices and can be used as biocatalytic and affinity biosensors. ${ }^{87,88}$ Phage-based amperometric sensors mostly rely on lytic phages as bacteria-specific recognition receptors and releasing agents of intracellular bacterial enzymes. This approach was initially applied to detect $E$. coli K12 cells using phage $\lambda$ as a recognition probe. The activity of released $\beta$-Dgalactosidase, a highly specific marker of $E$. coli, was measured using $p$-aminophenyl- $\beta$-D-galactopyranoside $(\beta$ PAPG) as a substrate, and the product of the reaction, $p$-aminophenol (PAP), was detected. The PhiX174 phage was also employed as another recognition probe to detect $E$. coli contamination in water, ${ }^{89}$ amperometrically. B. cereus and $M$. smegmatis cells were also successfully detected by combining phage typing and cell marker enzyme activity, using B1-7064 and D29 phages, respectively. This was done by measuring the activities of alpha-glucosidase and beta-glucosidase enzymes. Laczka and the group used a phagemid system to detect $E$. coli TG1 cells through alkaline phosphatase activity. ${ }^{90}$ The phagemid was constructed using a bacteriophage, M13KO7, as a helper phage and a commercial plasmid, pFLAG-ATS-BAP, which contained a gene encoding the reporter enzyme, alkaline phosphatize. M13KO7 is a nonlytic phage that cannot replicate in the cells; therefore, it overproduces enzymes in the cells. This also enhanced the sensitivity of the assay as $1 \mathrm{CFU} \mathrm{mL}{ }^{-1}$ bacterial cell could be detected within $3 \mathrm{~h}$.

Several researchers have also used EIS to detect $E$. coli cells using biotin displaying $\mathrm{T} 4$ phage $\mathrm{L}^{91}$ and wild type $\mathrm{T} 4$ phage covalently immobilized on screen-printed carbon electrode arrays for direct impedimetric detection of E. coli K12 cells. ${ }^{92} E$. coli cells were detected in a concentration range from $10^{4}$ to $10^{8}$

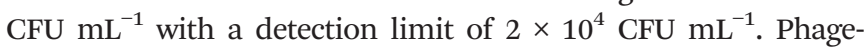
modified magnetic beads have also been used to capture and concentrate bacteria in the samples, which were then integrated with impedance detection. Leung et al. improved the LOD down to $10^{3} \mathrm{CFU} \mathrm{mL}^{-1} \cdot{ }^{93}$ Shabani et al. detected Bacillus anthracis Sterne vegetative cells using gamma phage modified screenprinted carbon electrode microarrays, ${ }^{94}$ and Bacillus anthracis cells were detected with a LOD of $10^{3} \mathrm{CFU} \mathrm{mL}^{-1} \cdot{ }^{95}$ 
Simultaneously, few studies have also shown that $\beta$-galactosidase can be detected with a response time of $\sim 100$ S over the range of $0.003-210 \mathrm{nM}^{96}$ S. typhimurium was

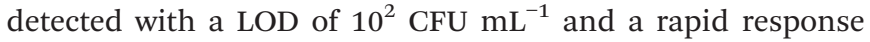
time of $<180$ s. Magnetoelastic (ME) sensors decorated with the E2 phage selected from the landscape f8/8 phage library were used to detect $S$. typhimurium in milk and fresh products such as spinach leaves, tomato, and cantaloupe. ${ }^{96-98}$ In a similar approach, methicillin-resistant S. aureus (MRSA) in spinach leaves was successfully detected using lytic phage 12600 as a bio-recognition probe. ${ }^{99}$ In addition, B. anthracis spores were detected using $\mathrm{ME}$ with a LOD of $10^{3} \mathrm{CFU} \mathrm{mL}^{-1}$. In addition, the filamentous E2 phage immobilized on a magnetostrictive millicantilever (MSMC) surface could detect $S$. typhimurium cells with a LOD of $5 \times$ $10^{8} \mathrm{CFU} \mathrm{mL}{ }^{-1} \cdot{ }^{100}$ In another report, the filamentous JRB7 phage was used to develop an MSMC sensor for detection of B. anthracis spores in water with a LOD of $10^{4} \mathrm{CFU} \mathrm{mL} \mathrm{m}^{-1}$ and $10^{5} \mathrm{CFU} \mathrm{mL} \mathrm{mL}^{-1}$ by using MSMCs in size of $1.4 \mathrm{~mm} \times 0.8 \mathrm{~mm} \times$ $35 \mathrm{~m}$ and $2.8 \mathrm{~mm} \times 1.0 \mathrm{~mm} \times 35 \mathrm{~m}$, respectively. ${ }^{101}$

As observed from the above-discussed studies, phagebased sensors show a natural affinity towards their target analytes and therefore are easier to prepare and are available at cheaper rates. The phage display techniques also use wildtype phages that can be genetically modified to display various protein molecules and bind with numerous target molecules. Moreover, owing to the enhanced stability of phages, these sensors have been shown to remain active for prolonged durations even under extreme environmental conditions. $^{102}$

3.2.3. Aptamers. Aptamers have been well documented as another fascinating molecular recognition element for pathogen detection. ${ }^{103}$ They are the most commonly used antibody alternatives. An aptamer is a synthetic short oligonucleotide sequence composed of either DNA or RNA molecules, which can bind to target analytes with high affinity and specificity. These nucleic acid molecular recognition elements were first described in 1990 by the Tuerk and Ellington laboratories. ${ }^{104}$ Aptamers also have several other advantages over antibodies, like their ease of conjugation with different reporter molecules, lower production cost, high reproducibility without batch-to-batch variations, and no requirements for animal hosts during production.

The recognition ability of aptamers comes from their conformation to three-dimensional structures that generate binding pockets for their intended targets. In general, the aptamer library comprises $10^{13}$ to $10^{15}$ different nucleic acid molecules. Systematic evolution of ligands by exponential enrichment (SELEX) identifies the newly designed aptamers with the highest affinity and specificity towards user-defined targets. ${ }^{105}$ Aptamers that bind to the intended target are retained and amplified by PCR amplification. This process is repeated for 10 to 20 rounds to enrich and increase the specificity of the aptamer pool. This approach of using aptamers as bio-recognition receptors has been applied to detect E. coli, ${ }^{106,107}$ M. tuberculosis, ${ }^{108-112}$ influenza viruses, ${ }^{113}$ HIV ${ }^{114-116}$ S. aureus, ${ }^{117-122}$ Salmonella species, ${ }^{123}$ Listeria species, ${ }^{124}$ Shigella species, ${ }^{125}$ Campylobacter species, ${ }^{126}$ Norovirus strains, ${ }^{127,128}$ Vibrio cholera, ${ }^{129}$ and Clostridium species. ${ }^{130}$ However, the real-life application of aptamers depends on their susceptibility to nuclease degradation. Hence, sample pre-treatment and enrichment steps are usually required before using an aptamer as a recognition probe.

Various bioreceptors used in different biosensors are summarised in Table 1.

\section{Using nanomaterials in POC devices for pathogen detection}

New developments in nanoscience have highly influenced medical and analytical sciences. Nanoscience has also affected detection analysis due to its versatile physicochemical properties that depend on particle size, shape and type. The development of electrodes for nanoscale sensors has become an emerging field and has gained widespread attention in diagnostic purposes. ${ }^{135}$ Nanomaterial-based (NMs) biosensors show enhanced sensitivity, rapid response time and reduced crosscontamination issues. These advantages can potentially facilitate the construction of POC devices ${ }^{28}$ for quick pathogen detection. Nanoparticles (NPs) also have a large surface-to-volume ratio, enabling various biomolecules to interact with them. The biomolecules are first immobilized to make the reaction sites available to interact with target species like bacteria, toxins, proteins, and nucleic acids. Owing to their biocompatibility and the ability to adsorb particles, NMs used in sensors often modify their electrode surfaces to enhance the overall functioning of the sensors. In addition, NMs strengthen the immobilization of the analytes on the bioreceptor surface by aiding the interactions between the two. Furthermore, NPs act as signalling molecules and allow for signal amplification during the sensing process. Table 2 summarizes the various NM-based biosensors used to detect different pathogens.

The primary motivation of nanoscale devices is to increase sensitivity, specificity and provide simple detection mechanisms. ${ }^{160,161}$ NM-based POC devices like biosensors have been rampantly used in recent years to detect various kinds of bacterial and clinical pathogens. NM-based sensors employ many or all of the properties of NPs, including their chemical, optical, magnetic, and electrical features, to detect pathogens. ${ }^{162}$ The molecular determination forces the enhancement of the sensors to produce POC devices that can perform rapid and inexpensive detection of several pathogens. ${ }^{163}$ NMs and nanostructures like carbon nanotubes, metal oxide NPs, magnetic NPs, metal nanoclusters, nanogels, and plasmonic nanomaterials have been employed in several studies to achieve this purpose. Recently three widely used NPs have been implemented in biosensing platforms, including gold nanoparticles (AuNPs), 
Table 1 Various bioreceptors used in different biosensors

\begin{tabular}{|c|c|c|c|c|}
\hline Bio-recognition receptors & Detection range & Pathogens detected & LOD & Ref. \\
\hline \multirow[t]{4}{*}{ Antibodies } & $1.0 \times 10^{3}$ to $1.0 \times 10^{7} \mathrm{CFU} \mathrm{mL}^{-1}$ & S. typhimurium & $5.0 \times 10^{2} \mathrm{CFU} \mathrm{mL} \mathrm{m}^{-1}$ & 131 \\
\hline & - & S. enterica & $10^{2}$ cells per $\mathrm{mL}$ & 64 \\
\hline & Up to $1 \times 10^{8}$ cells per $\mathrm{mL}$ & E. coli and S. epidermidis & $2.5 \times 10^{2}$ cells per $\mathrm{mL}$ & 132 \\
\hline & - & E. coli, B. subtilis and S. aureus & $1.5 \times 10^{4}$ cells per $\mathrm{mL}$ & 133 \\
\hline \multirow[t]{6}{*}{ Bacteriophage } & - & Clostridium botulinum & $3.33 \times 10^{-14} \mathrm{~mol}$ & 134 \\
\hline & $10^{3}-10^{6} \mathrm{CFU} \mathrm{mL}^{-1}$ & E. coli and S. aureus & $10^{3} \mathrm{CFU} \mathrm{mL} \mathrm{m}^{-1}$ & 84 \\
\hline & 20 to $2000 \mathrm{CFU} 100 \mathrm{~mL}^{-1}$ & Enterobacteriaceae & $5 \times 10^{4} \mathrm{CFU} \mathrm{mL} \mathrm{mL}^{-1}$ & 90 \\
\hline & - & E. coli & $10^{3} \mathrm{CFU} \mathrm{mL} \mathrm{m}^{-1}$ & 95 \\
\hline & 0.003 to $210 \mathrm{nM}$ & E. coli & - & 96 \\
\hline & $7 \times 10^{2}$ to $7 \times 10^{8} \mathrm{CFU} \mathrm{ml}^{-1}$ & E. coli & $10^{4} \mathrm{CFU} \mathrm{mL} \mathrm{m}^{-1}$ & 83 \\
\hline \multirow[t]{10}{*}{ Aptamers } & $10-10^{4} \mathrm{CFU} \mathrm{mL} \mathrm{m}^{-1}$ & E. coli $\mathrm{O} 157: \mathrm{H7}$ & $10^{2} \mathrm{CFU} \mathrm{mL} \mathrm{m}^{-1}$ & 108 \\
\hline & $10^{4}-10^{7} \mathrm{CFU} \mathrm{ml}^{-1}$ & Escherichia Coli 0157:H7 & $4.5 \times 10^{3} \mathrm{CFU} \mathrm{mL}^{-1}$ & 109 \\
\hline & $1 \times 10^{-7}-2 \times 10^{-6} \mathrm{M}$ & E. coli & - & 110 \\
\hline & $0.1 \mathrm{nM}$ to $10 \mathrm{nM}$ & E. coli & - & 111 \\
\hline & 10 to $1 \times 10^{6} \mathrm{CFU} \mathrm{mL}^{-1}$ & S. aureus & $1.0 \mathrm{CFU} \mathrm{mL} \mathrm{m}^{-1}$ & 119 \\
\hline & $5 \times 10^{2} \mathrm{CFU} \mathrm{ml} l^{-1}$ to $5 \times 10^{9} \mathrm{CFU} \mathrm{ml}^{-1}$ & S. aureus & $10^{5}-10^{6}$ cells per $\mathrm{mL}$ & 120 \\
\hline & $0.01-10 \mu \mathrm{g} \mathrm{mL}^{-1}$ & S. aureus & $6 \mathrm{ng} \mathrm{mL}^{-1}$ & 121 \\
\hline & $4.1 \times 10^{1}-4.1 \times 10^{5} \mathrm{CFU} \mathrm{mL}^{-1}$ & S. aureus & $41 \mathrm{CFU} \mathrm{mL} \mathrm{mL}^{-1}$ & 122 \\
\hline & $2.4-2.4 \times 10^{3} \mathrm{CFU} \mathrm{mL}^{-1}$ & Salmonella & $3 \mathrm{CFU} \mathrm{mL} \mathrm{m}^{-1}$ & 125 \\
\hline & 20 to $2 \times 10^{6} \mathrm{CFU} \mathrm{mL}^{-1}$ & L. monocytogenes & $20 \mathrm{CFU} \mathrm{mL}^{-1}$ & 126 \\
\hline
\end{tabular}

silver nanoparticles (AgNPs), and platinum nanoparticles (PtNPs). These NPs are employed as signalling molecules in various electrochemical sensor assays for pathogen detection. ${ }^{164,165}$ In addition, there are more modified NPs available that are applied for pathogen detection, like quantum dots and graphene oxide. We will discuss biosensors based on these two categories of nanoparticles in the subsequent sections.

\subsection{Quantum dots (QDs)}

In a study in 2014, Liu and colleagues developed an effective isothermal amplification process using AuNPs. This low-cost paper platform could detect pathogenic bacteria and showed a detection limit of $0.5 \mathrm{pg} \mu \mathrm{L}^{-1}$ genomic RNA from viable $L$. monocytogenes. This assay had a high specificity and gave the result within $15 \mathrm{~min}$. This assay was also tested on real samples like milk and cheese; it could be used as a POCbased analysis for foodborne pathogenic bacteria. ${ }^{166}$ Recently, quantum dots (QDs) have also seen massive potential in the sensor field in NP-based technology owing to their size-dependent optical and electronic properties. ${ }^{167}$ QDs derive their energy from tiny materials that efficiently work with concentrated samples into a single point, thereby charging them with electric power.

According to quantum theory, QD NPs have distinct energy levels like an individual atom. ${ }^{168}$ The QD core-shell can detect biomolecules following the florescent process. Xiong et al. observed that core-shell ZnO QDs possessed yellow and green emission and could perform biological labelling. This novel approach involving QD core-shell NPs was stable in aqueous solutions and could easily detect biological samples or liquid analytes. The concentration of live cells was $0.2 \mathrm{mg} \mathrm{mL}^{-1}$ and was protected with this coreshell QD, which could infiltrate into the cytoplasm (Fig. 2). ${ }^{169}$
The significant advantage of ZnO-based core-shell QDs was their non-toxic and safe nature that could be used in live cells, including human cells. This is an exciting approach in biological samples that do not use complex compounds or reagents.

Compared to traditional fluorescent dyes such as fluorescein isothiocyanate (FITC), QDs display brighter fluorescence intensities and last longer. ${ }^{170,171}$ Due to the advantages of QDs over traditional fluorescent dyes, they are widely used as fluorescent labels ${ }^{172}$ instead of traditional dyes. They are used as biorecognition elements in a wide range of immunoassays to detect various foodborne pathogens.

\subsection{Graphene oxide (GO)}

NPs have been widely used in sensing platforms for in vitro studies. Such studies use matrix modifications on the electrode surface for signal amplification purposes. The detailed mechanisms correlating to the changes of intrinsic physicochemical and optoelectronic properties play different roles in instantaneously identifying microbes by changes in their color. They act as sensory probes and therapeutic agents and can be used in molecular diagnosis and drug discovery for biological, clinical, and chemical purposes. NMs are vital for pathogen detection and are used in various easy-to-engineer biosensor devices with finely-tuned configurations at the nanoscale level. For example, graphene is a two-dimensional carbon NM with unique properties like high electrical conductivity, large surface area, and mechanical and thermal stability. ${ }^{35}$ Graphene and its derivatives, graphene oxide (GO), reduced graphene oxide (rGO), and graphene nanoribbons (GN), have also exhibited exciting biosensing applications to detect a variety of pathogens. ${ }^{173}$ Based on the diverse 
Table 2 Nanomaterial-based biosensors used to detect different pathogens

\begin{tabular}{|c|c|c|c|c|}
\hline $\begin{array}{l}\text { Nanoparticles used during } \\
\text { bacterial sensing }\end{array}$ & Pathogens detected & Detection range & $\begin{array}{l}\text { Detection } \\
\text { limit }\end{array}$ & Ref. \\
\hline \multirow[t]{5}{*}{ Graphene oxide } & E. coli & $10^{-6}$ to $10^{-16} \mathrm{M}$ & $1 \times 10^{-16} \mathrm{M}$ & 136 \\
\hline & E. coli & $1 \times 10$ to $1 \times 10^{4} \mathrm{CFU} \mathrm{mL} \mathrm{m}^{-1}$ & $10 \mathrm{CFU} \mathrm{mL}^{-1}$ & 137 \\
\hline & S. aureus & 1 to $40 \mathrm{nmol} \mathrm{L}^{-1}$ & $0.5 \mathrm{nmol} \mathrm{L}^{-1}$ & 138 \\
\hline & M. tuberculosis & $1.0 \times 10^{-6}$ to $1.0 \times 10^{-12} \mathrm{M}$ & $7.96 \times 10^{-13} \mathrm{M}$ & 139 \\
\hline & P. aeruginosa & $1.2 \times 10^{1}-1.2 \times 10^{7} \mathrm{CFU} \mathrm{mL}^{-1}$ & $12 \mathrm{CFU} \mathrm{mL} \mathrm{m}^{-1}$ & 140 \\
\hline \multirow[t]{8}{*}{ Quantum dots } & S. aureus and $E$. coli & 0 to $9 \times 10^{7} \mathrm{CFU} \mathrm{ml}^{-1}$ & - & 141 \\
\hline & M. tuberculosis & $1 \times 10^{-11}$ to $1 \times 10^{-7} \mathrm{M}$ & $8.948 \times 10^{-13} \mathrm{M}$ & 142 \\
\hline & S. typhimurium & $1.0 \times 10^{2}$ to $1.0 \times 10^{7} \mathrm{CFU} \mathrm{mL}^{-1}$ & $43 \mathrm{CFU} \mathrm{mL}^{-1}$ & 143 \\
\hline & S. typhimurium & $10^{3}$ to $10^{7} \mathrm{CFU} \mathrm{ml} \mathrm{ml}^{-1}$ & $10^{3} \mathrm{CFU} \mathrm{mL} \mathrm{m}^{-1}$ & 144 \\
\hline & S. typhimurium & $1.0 \times 10^{4}$ to $1.0 \times 10^{6} \mathrm{CFU} \mathrm{mL}^{-1}$ & $5.4 \times 10^{3} \mathrm{CFU} \mathrm{mL}^{-1}$ & 145 \\
\hline & E. coli $\mathrm{O} 157: \mathrm{H} 7$ & - & 6.660 CFU mL $\mathrm{mL}^{-1}$ & 146 \\
\hline & S. aureus & - & $1.070 \times 10^{1} \mathrm{CFU} \mathrm{mL}^{-1}$ & 146 \\
\hline & $V \cdot$ parahaemolyticus & - & $2.236 \times 10^{1} \mathrm{CFU} \mathrm{mL}^{-1}$ & 146 \\
\hline \multirow[t]{5}{*}{ AuNPs } & E. coli $0157:$ H7 & $10^{1}-10^{6} \mathrm{CFU} \mathrm{ml}^{-1}$ & $10^{1} \mathrm{CFU} \mathrm{ml} \mathrm{m}^{-1}$ & 147 \\
\hline & $\begin{array}{l}\text { Escherichia coli } \mathrm{O} 157: \mathrm{H} 7, \\
\text { Vibrio parahaemolyticus, } \\
\text { salmonella, Staphylococcus } \\
\text { aureus, listeria monocytogenes, } \\
\text { Shigella }\end{array}$ & - & $1-9$ cells $\mathrm{mL}^{-1}$ & 148 \\
\hline & V. cholera & $3.2 \times 10^{4}$ to $28 \times 10^{4}$ cells $\mathrm{ml}^{-1}$ & - & 149 \\
\hline & P. aeruginosa and $V$. cholerae & - & $\sim 10^{2} \mathrm{CFU}$ & 150 \\
\hline & S. enteritidis & $10^{4}$ and $10^{8} \mathrm{CFU} \mathrm{mL} \mathrm{m}^{-1}$ & $10^{3} \mathrm{CFU} \mathrm{mL}^{-1}$ & 151 \\
\hline \multirow[t]{5}{*}{ AgNPs } & $\begin{array}{l}\text { S. flexneri, E. coli } \mathrm{O} 157: \mathrm{H} 7, \\
\text { L. mono and } S . \text { aureus }\end{array}$ & $10^{1}$ to $10^{7} \mathrm{CFU} \mathrm{mL} \mathrm{m}^{-1}$ & $1.5 \mathrm{CFU} \mathrm{mL} \mathrm{m}^{-1}$ & 152 \\
\hline & L. monocytogenes & - & $0.015 \mathrm{ng} \mathrm{mL}{ }^{-1}$ & 153 \\
\hline & S. enterica & - & $0.013 \mathrm{ng} \mathrm{mL}^{-1}$ & 153 \\
\hline & S. typhi & $10^{3}-10^{5}$ CFU $\mathrm{mL}^{-1}$ & $10^{3} \mathrm{CFU} \mathrm{mL}^{-1}$ & 154 \\
\hline & H. pylori & - & $10 \mathrm{CFU} \mathrm{mL} \mathrm{m}^{-1}$ & 155 \\
\hline \multirow[t]{4}{*}{ PtNPs } & E. coli $\mathrm{O} 157: \mathrm{H} 7$ & $4.0 \times 10^{2}$ to $4.0 \times 10^{8} \mathrm{CFU} \mathrm{mL}^{-1}$ & $91 \mathrm{CFU} \mathrm{mL}^{-1}$ & 156 \\
\hline & S. typhimurium & $10-15$ CFU mL ${ }^{-1}$ & $2 \mathrm{CFU} \mathrm{mL} \mathrm{m}^{-1}$ & 157 \\
\hline & E. coli $\mathrm{O} 157: \mathrm{H} 7$ & $5 \times 10^{2} \mathrm{CFU} \mathrm{mL} \mathrm{mL}^{-1}$ to $1 \times 10^{7} \mathrm{CFU} \mathrm{mL}^{-1}$ & $1.08 \times 10^{2} \mathrm{CFU} \mathrm{mL} \mathrm{m}^{-1}$ & 158 \\
\hline & L. innocua & - & $100 \mathrm{CFU} \mathrm{mL}^{-1}$ & 159 \\
\hline
\end{tabular}

pathogen sensing processes, we divided our study into the two following sections.

4.2.1. Fluorescence-based GO method and its applications. Due to the increasing demand for rapid and robust techniques, researchers have reported sensitive sensing of pathogens using GO-based sensors. ${ }^{174}$ GO was successfully synthesized via the Hummers method in a recent study by employing $\mathrm{MnO}_{2} \mathrm{O}_{7}$ to oxidize graphite. ${ }^{175}$ In another study about rotavirus detection using a GO-based immunebiosensor, the rotavirus was captured by an antibody immobilized on GO sheets using rotavirus-specific antibody. The binding was monitored by observing the fluorescence quenching of GO during fluorescence resonance energy transfer between GO and gold NP-labeled secondary antibodies. This platform utilized antibodies-QDs as capture probes that fluorescence upon excitation with a laser source. Then GO was added to quench the fluorescence in the absence of the target pathogen. However, in the presence of a target, the interaction between the target and immobilized probe hinders the interaction of the probe and GO, thereby causing lower quenching. ${ }^{176}$ In another similar study, a GO-based fluorescent aptasensor was used to detect Salmonella typhimurium. This study

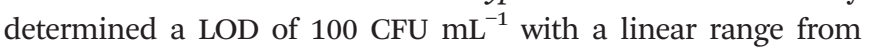

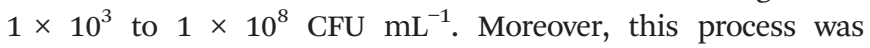
label-free, sensitive and specific, and could be applied for real sample analysis for pathogen detection. ${ }^{177}$ Thus, these discoveries show the great potential of GO-based biosensors for pathogen detection, food safety testing, clinical diagnosis and environmental monitoring. Additionally, these newly advanced methodologies are simple to use, have high portability, and do not involve complex steps.

4.2.2. Electrochemical-based GO method and its application. Recently numerous studies have been carried out based on GO-based electrochemical sensors that can successfully detect various pathogens. ${ }^{178,179}$ Various sensitive and specific label-free graphene-based electrical biosensors have been reported that can detect different bacteria species. One such study demonstrated the development of a labelfree graphene-interfaced capacitor chip for capturing bacterial cells. ${ }^{180}$ The authors prepared graphene via chemical vapour deposition and functionalized it by noncovalent attachment of 1-pyrenebutanoic acid succinimidyl ester in methanol for $2 \mathrm{~h}$. The anti-E. coli antibodies were then immobilized on the functionalized electrodes. This graphene-based electrical chip could detect E. coli $\mathrm{O} 157: \mathrm{H7}$ bacteria without the involvement of any chemical mediators. Upon binding with the target $E$. coli bacteria, a significant increase in the conductance was observed. This sensor gave a LOD of 10 cells per $\mathrm{mL}$ with a detection range of 10 to 100 cells per $\mathrm{mL}$. 


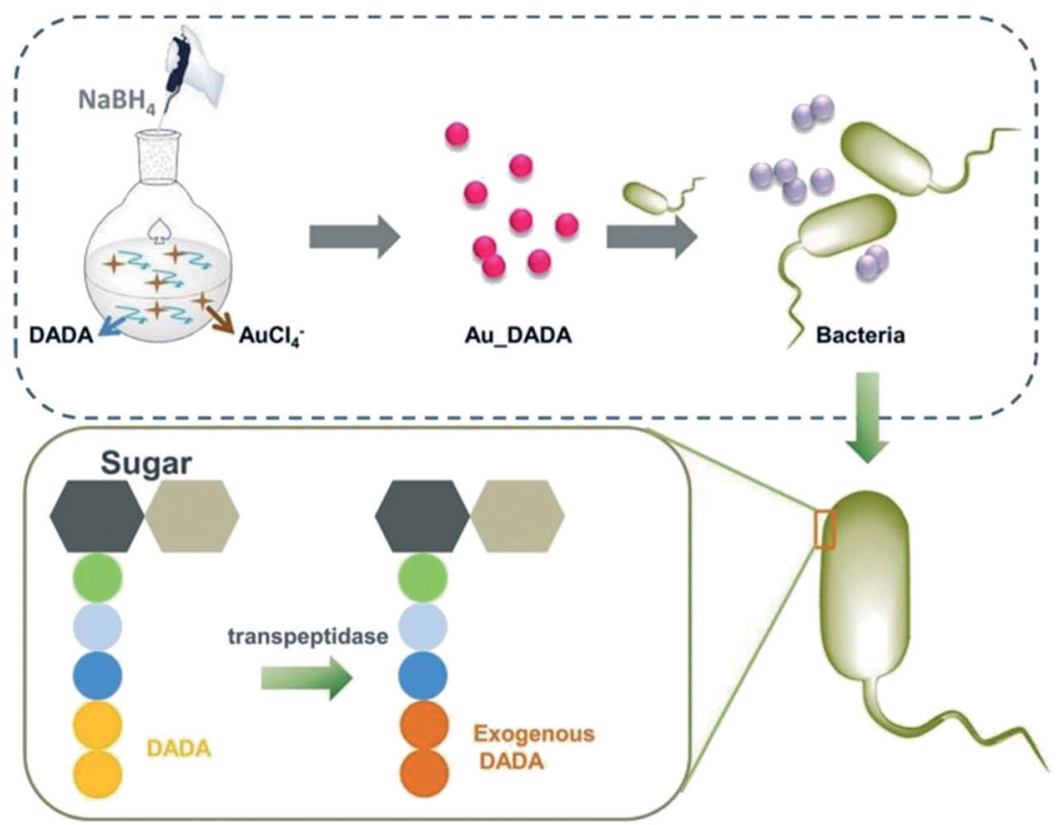

Fig. 2 Schematic representation of modified AuNPs and D-amino acid-modified QDs and the color change of peptidoglycan after incubation with newly modified synthesized AuNPs. Reproduced with permission from ref. 169.

Another pathogen-detection system was reported in 2012 that was based on the quenching property of GO. ${ }^{181}$ In this work, graphene was printed onto water-soluble silk, yielding a fully biointerfaced sensing platform. Antimicrobial peptides were then immobilized onto graphene via self-assembly and employed to detect bacteria at a single-cell level. The wireless sensor was fabricated using a resonant coil, which allowed the integration of the sensing device onto the tooth for realtime detection of bacteria in saliva. This approach of interfacing graphene nanosensors and biomaterials showed an extensive detection of biochemical and pathogen targets. In another study, an rGO-gold NP composite was used as the sensing platform to detect Mycobacterium tuberculosis. A DNA electrochemical biosensor was developed using rGO and AuNPs that showed good sensitivity and stability. A nanoparticle-polyaniline nanocomposite was used as a tracer in the experiment. The linear range of detection was noted to be $1.0 \times 10^{-15}$ to $1.0 \times 10^{-9} \mathrm{M}^{182}$

Another electrochemical genosensor based on a multiwalled carbon nanotube-chitosan-bismuth complex and lead sulfide NPs was developed recently to detect pathogenic Aeromonas. The detection limit was recorded as $1.0 \times 10^{-14}$ M. During real sample analysis, Aeromonas spiked up, like in tap water. In such cases, the LOD was found to be lower than $10^{2} \mathrm{CFU} \mathrm{mL}{ }^{-1}$. This study showed a rapid and sensitive detection process of bacteria samples and could be potentially used for food safety and environmental monitoring applications. ${ }^{183}$ Another excellent research study involved a chemiresistive immunosensor based on a carbon nanotube that could simultaneously detect Escherichia coli O157:H7 and the bacteriophage T7. This sensor demonstrated good sensitivity (LOD $10^{3} \mathrm{CFU} \mathrm{mL}^{-1}$ for E. coli and $10^{3} \mathrm{PFU} \mathrm{mL^{-1 }}$ for bacteriophage, respectively) along with an excellent dynamic range (linear range for E. coli $10^{3} \mathrm{CFU}$ $\mathrm{mL}^{-1}$ to $10^{7} \mathrm{CFU} \mathrm{mL}{ }^{-1}$ and bacteriophage $10^{2} \mathrm{PFU} \mathrm{mL}{ }^{-1}$ to $10^{7} \mathrm{PFU} \mathrm{mL}{ }^{-1}$, respectively) and a fast response time of $5 \mathrm{~min}$ in the case of bacteriophage detection and $60 \mathrm{~min}$ to detect bacteria. ${ }^{184}$ The above stated examples are some of the recent advances in the development and application of graphenebased fluorescence and electrochemical biosensors, which can be potentially studied and further developed as POC devices for food safety and in the biomedical field. In Table 3, we have discussed the advantages and disadvantages of these two processes with examples of sensor matrices in detail.

\section{Incorporation of microfluidic POC devices for pathogen detection}

Several efforts have been made to develop innovative methodologies to overcome the drawbacks posed during POC development. As a result, many alternative pathogen detection and diagnosis techniques are available based on POCs, such as DNA-based biosensors, immunosensors, aptamer sensors, smartphone-assisted sensors, microfluidic platforms, and wearable sensors. Some of these modern pathogen detection approaches and advancements in this field will be discussed in the subsequent sections.

Microfluidic devices are fluid handling devices in which a minute volume of the sample flows into channels that have dimensions ranging from a few to hundreds of microns. Microfluidics has shown growing potential in different applications in recent years, especially in biosensors. ${ }^{185}$ The use of microfluidics has demonstrated several advantages, 
Table 3 The advantages and limitation of fluorescence and electrochemical-based GO methods

\begin{tabular}{|c|c|c|c|c|}
\hline $\begin{array}{l}\text { Fluorescence-based } \\
\text { GO method }\end{array}$ & $\begin{array}{l}\text { GO acts as an excellent fluorescence quencher } \\
\text { and thus allows for highly sensitive } \\
\text { bio-sensing }\end{array}$ & $\begin{array}{l}\text { GO can be further purified to remove } \\
\text { excess oxygen moieties and } \\
\text { functionalized to obtain better } \\
\text { fluorescence peaks }\end{array}$ & $\begin{array}{l}\text { GO-based aptasensor to } \\
\text { detect } S \text {. typhimurium } \\
\text { GO-based immuno } \\
\text { biosensor }\end{array}$ & $\begin{array}{l}177 \\
176\end{array}$ \\
\hline $\begin{array}{l}\text { Electrochemical-based } \\
\text { GO method }\end{array}$ & $\begin{array}{l}\text { The large surface area of GO and superior } \\
\text { electrical properties like high charge mobility } \\
\text { and changeable conductance allow for highly } \\
\text { sensitive detection of the analytes }\end{array}$ & $\begin{array}{l}\text { Bio-anchoring occurs on the sensor's } \\
\text { surface without any observable } \\
\text { changes in the sensor's electrical } \\
\text { properties during detection. Also, } \\
\text { such sensors use redox-mediators } \\
\text { that affect the signal transduction } \\
\text { process }\end{array}$ & $\begin{array}{l}\text { Label-free } \\
\text { graphene-interfaced } \\
\text { capacitor chip to detect } \\
\text { E. coli cells } \\
\text { GO-based fully } \\
\text { biointerfaced, wireless } \\
\text { sensing platform to } \\
\text { detect bacterial cells } \\
\text { rGO-gold NP } \\
\text { composite-based } \\
\text { biosensor to detect } \\
\text { Mycobacterium } \\
\text { tuberculosis } \\
\text { MWCNT-Chi-Bi-based } \\
\text { electrochemical } \\
\text { genosensor to detect } \\
\text { Aeromonas }\end{array}$ & 180 \\
\hline
\end{tabular}

such as 1) minimal amount of sample or reagent requirements which reduce the overall cost and the risk of contamination, 2) the target analyte easily gets localized on the sensing area because of the small dimension of the chip, 3) the analysis time is reduced because of the quick mass transport within the microchannels, and 4) the functionalization of the inner surface of the channels that are typically made of plastic, polydimethylsiloxane (PDMS) or glass, thus, enabling the capture of the analyte under continuous flow conditions.

Label-free electrical and electrochemical biosensors have received considerable attention due to their compatibility with microfabrication techniques involving various microfluidic channels. In one of the studies, researchers constructed an on-chip artificial pore to sense bacterial pathogens. The microfluidic chip was fabricated using PDMS. The channels were functionalized with proteins that could specifically bind to the bacterial cell-surface receptors. The capture of cells onto the channels blocks the current flow. Thus, the duration of the recent pulse can differentiate between the specific and nonspecific cells. This method has been used to detect murine erythroleukemia cells. The number of cells can be determined by measuring the change in solution conductivity after cell lysis that occurs with the release of ions from the cells. ${ }^{186}$ Another study demonstrated the fabrication of a microfluidic silicon chip with thin-film platinum electrodes. The sensing chamber was functionalized with specific antibodies for the target bacteria.

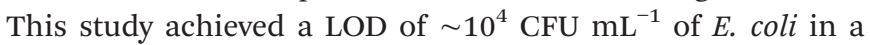
tiny chamber of $2 \mu \mathrm{m}$ height. ${ }^{187}$

The integration of LAMP amplification onto a lab-on-chip device to detect Salmonella is another thriving area in microfluidics devices $(\mu \mathrm{D})$ that has been reported. ${ }^{188}$ In this study, the pathogen was detected by visualizing the SYBR green I dye color change. An inexpensive microfluidic paper device was fabricated via the wax printing technique using a solid ink printer. This study achieved a LOD of $2.6 \times 10^{7} \mathrm{CFU}$ $\mathrm{mL}^{-1}$ during Salmonella live-cell detection and showed great sensitivity. The authors reported this method to have great potential for POC testing purposes. Other $\mu \mathrm{D}$ are also available for pathogen detection like microfluidic protein/ enzyme-based pathogen sensors, microfluidic antibody/ aptamer sensors and microfluidic cell-based pathogen sensors. Moreover, numerous frameworks have been already utilized to detect pathogens in manageable samples under research environment conditions. In one of the recent studies in the year 2020, the authors fabricated a good selectivity, stability and low-cost 3D paper-based microfluidic electrochemical glucose biosensor based on rGP-TEPA/PB sensitive film with a detection limit of $25 \mu \mathrm{M}$ and with a linear range of $0.1-25 \mathrm{mM}$. The novelty of their work was the design of sensing metrics which provided a high conductivity and large surface area for good electrocatalytic reduction activity. ${ }^{189}$ Around the same time, researchers have reported a proof-of-concept using a paper-based microfluidic device for high throughput multiplexed analysis. The main appealing part of this system is the disposable low-cost microfluidic device with a LOD of $3 \times 10^{-5}$ mol L ${ }^{-1} \cdot 190$ Meanwhile, applications of thread-based microfluidics are also in demand. In a new study, a thread-based microfluidic fuel cell with graphite rod electrodes was developed by the capillary driven reaction of electrolytes. ${ }^{191}$ Hence, based on these proofs of concept sensing platforms will help to detect various pathogens in the near future.

\section{Portable POC devices available for pathogen detection}

Many major classes of portable POC diagnostics devices were developed for pathogen detection. The most commonly used 
POC devices include utilizing lateral flow tests (LFT) and their lateral flow assays (LFA).

\subsection{Lateral flow tests}

The principle of LFT relies on detecting the pathogen by utilizing a capillary force to flow the sample across the membrane and gather labelling molecules on the embedded capturing antibody. LFT was used primarily for pathogen detection $^{192}$ in food, ${ }^{193}$ and it was commercialized for the detection of SARS viruses, ${ }^{194}$ rotaviruses, ${ }^{195}$ streptococci, microbes like Bacillus species, ${ }^{196}$ and meat species. ${ }^{197,198}$ However, LFT is simple, easy to use, and requires a low cost to manufacture; it cannot perform complex laboratory procedures and requires high accuracy assays such as nucleic acid tests. ${ }^{35}$ Therefore, significant effort has been focused on integrating signal amplification sensitivity with the rapid and facile sensing modality of LFT. In this regard, a CD-based microfluidic process was utilized to develop separate LFTs that could detect the LAMP amplicon of the H1N1 influenza virus by amplifying $\mathrm{H} 1$ and $\mathrm{M}$ genes. ${ }^{199}$

Each microchip consists of an inlet to inject the LAMP reagent into an amplification chamber. A zigzag-shaped micro dispenser channel was allocated to LAMP solution equally in three different compartments. $2 \mu \mathrm{L}$ of the sample was injected into the inlet. By leveraging centrifuge speeds and amplification times, the LAMP amplicon was detected with a sensitivity of 10 copies per sample ( $7 \mu \mathrm{L}$ samples). In one study, Rohrman et al. integrated RPA with LFT to detect 10 copies of HIV DNA samples in 15 minutes (Fig. 3A). ${ }^{200}$ The amplicon was detected using LFT of single bacteria detection $^{201}$ (Fig. 3B). In general, the LAMP amplification method has been employed more frequently than other isothermal amplification methods to develop POC devices for pathogen detection. ${ }^{44}$

\subsection{Incorporation of the screen-printed electrode (SPE) in various biosensor devices}

Several platforms have been developed based on screenprinted technology, ${ }^{202}$ which allows for POC diagnostic application for pathogen detection and quantification. For instance, screen-printed electrode (SPE) technologies are widely used in POC devices to perform electrochemical sensing modalities of DNA amplification products by interchelating redox molecules with DNA amplicons ${ }^{35,202,203}$ (Fig. 4A). In a study by Safavieh et al., a microfluidic chip was developed to detect and quantify $E$. coli bacteria with a LOD

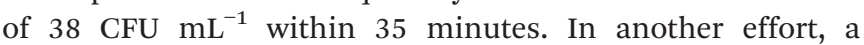
portable roll to roll cassette ${ }^{204,205}$ device was used to detect and quantify pathogens, E. coli and S.aureus, ${ }^{206,207}$ with a sensitivity of $30 \mathrm{CFU} \mathrm{mL} \mathrm{m}^{-1}$ and $200 \mathrm{CFU} \mathrm{mL}^{-1}$, respectively. In a closely similar study, Tolba et al. leveraged bacteriophageencoded peptidoglycan hydrolases to capture and detect Listeria on a gold SPE based on EIS. The LOD was recorded to be $1.1 \times 10^{4}$ and $10^{5} \mathrm{CFU} \mathrm{mL}^{-1}$ in bacteria samples of pure

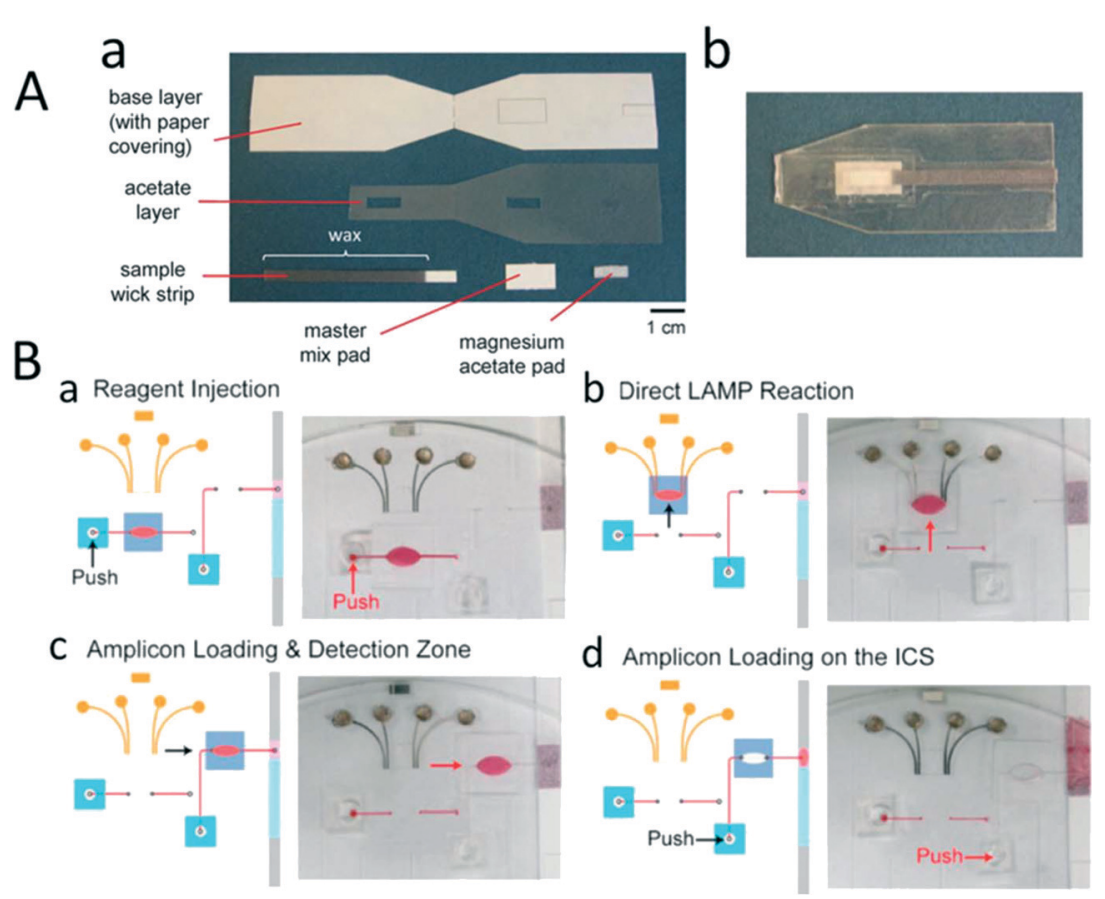

Fig. 3 Lateral flow test for nucleic acid amplification. (A) Lateral flow test strip for detection of the recombinase polymerase amplification product. (a) This consists of a base layer, an acetate layer to isolate different regions, and two pads to apply the master mix and magnesium acetate. The sample was added to the master mix-pad and, after amplification, was detected with a lateral flow strip. (b) Image of the integrated RPA paper chip. (B) Integrated LAMP and LFT in sliding chambers. (a) LAMP reagents were loaded into the reaction chamber by pressing the releasing reservoir with a finger and (b) the chamber slider to perform the LAMP reaction. (c) The chamber was sided into the detection region, and (d) the sample was pushed to load the amplicon on lateral chromatography strips (LCS). Reproduced with permission from ref. 200 and ref. 201. 


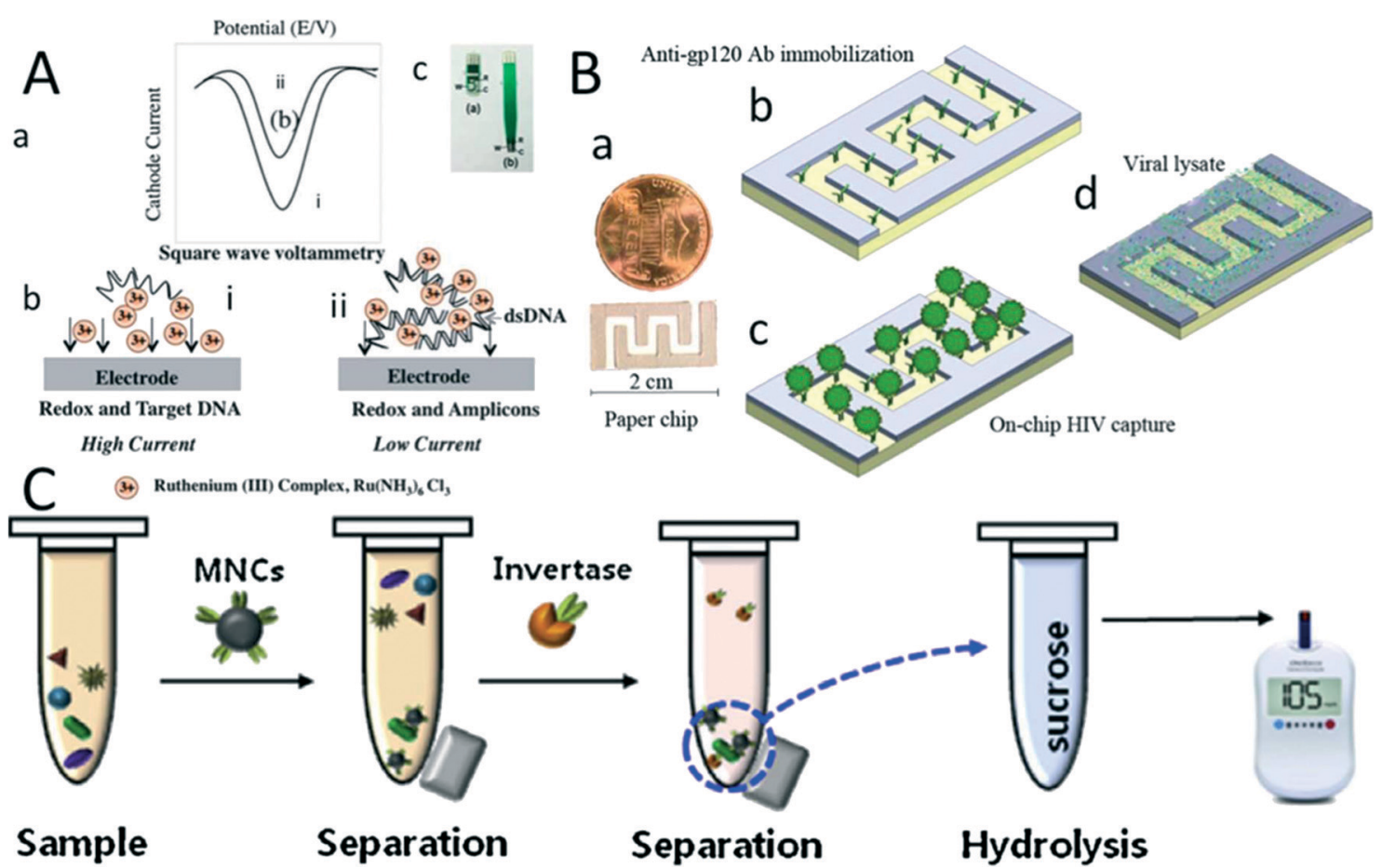

Fig. 4 Pathogen detection on screen-printed electrode chips. (A) Detection of a real-time LAMP-amplicon on a carbon SPE chip using ruthenium hexamine redox. (a) SWV for detection of the LAMP product in (i) the absence and (ii) the presence of a double-stranded DNA amplicon. (b) Schematic of electrochemical sensing modality for LAMP amplicon detection using ruthenium hexamine redox. (c) Image of the carbon screenprinted electrode. (B) (a) Graphene modified silver electrode paper microchip for detection of HIV-1 virus. (b) Anti gp-120 was immobilized on the surface of the paper chip. (c) HIV-1 viruses were captured on the chip. (d) The virus was lysed, and the nano-lysate was measured to detect the virus using impedance spectroscopy. (C) Salmonella bacteria detection using a glucose meter. Antibody conjugated with magnetic beads was used to capture Salmonella in the milk sample. Then it was separated by a magnet. The sample was conjugated with invertase and dispersed in sucrose. The conjugated antibody-bacteria invertase complex hydrolyses sucrose into glucose, which can be monitored by a glucose meter. Reproduced with permission from ref. 210 and ref. 211.

culture and $2 \%$ spiked milk, respectively. ${ }^{208}$ In addition, the SPE has been widely employed to detect toxins and antigens from pathogens. ${ }^{209}$ Viruses have also been detected using SPE-based electrical sensing techniques. For example, antigp-120 was immobilized on the surface of a paper microchip, and $10^{8}$ copies $\mathrm{mL}^{-1}$ of HIV was detected with an impedance magnitude of $1 \mathrm{kHz}$ frequency ${ }^{210}$ (Fig. 4B).

A glucose meter is another primary device that can detect microbial pathogens. The low-cost and disposable SPE and rapid electrochemical sensing modality make the glucose meter an appealing technology as a POC diagnostic device. The principle of this device is based on the functionalization of antibodies with invertases. These antibodies are conjugated with the pathogens and then dispersed in a sucrose solution. The hydrolysis of sucrose by invertase releases glucose into the solution. This is found to be proportional to the concentration of the pathogens and can be monitored by a glucose meter $^{212,213}$ (Fig. 4C). A glucose meter detects various microbial pathogens like Salmonella enterica spiked in milk with a LOD of $10 \mathrm{CFU} \mathrm{mL}{ }^{-211}$. With a similar approach, E. coli in a potable water sample is detected with a lactose substrate, achieving a LOD of $2 \times 10^{7} \mathrm{CFU} \mathrm{mL}^{-1}$. E. coli bacteria produce $\beta$-galactosidase that transforms lactose into glucose, which is detected by the glucose meter.

\subsection{Utilization of smartphones}

With the advancements in technology, smartphones can now be integrated with various sensing modalities and can be easily implemented in pathogen detection. Smartphones can record sensing patterns of optical, fluorescence, colorimetric, and electrochemical/electrical techniques to detect bioanalytes ${ }^{214}$ using their features like high-resolution cameras, facile video documenting systems, and integrated applications with portable electrochemical transducers. Various POC platforms based on smartphones for pathogen detection and their analytical performances are summarised in Table 4.

Shafiee et al. detected E. coli bacteria conjugated with AuNPs on a paper chip using a smartphone (Fig. 5A). ${ }^{226}$ Techniques like Mie scattering have also been used to detect bacteria in real beef samples ${ }^{217}$ (Fig. 5B). In another study, a valveless microfluidic device was fabricated via the hot embossing method to detect genes of stx2 and eaeA from $E$. coli and mecA and vick of $S$. aureus by using optical fluorescence techniques (Fig. 5C). ${ }^{220}$ Rodriguez-Manzano et $a .^{219}$ have developed a single-molecule detection method using LAMP and colorimetric dye, hydroxy naphthol blue (HNB). A sample consisting of HCV nucleic acid was 
Table 4 Portable POC diagnostic devices integrated with smartphones for pathogen detection

\begin{tabular}{|c|c|c|c|c|}
\hline Sensing modality & Bio-analyte & $\begin{array}{l}\text { Limit of } \\
\text { detection }\end{array}$ & Detection range & Ref. \\
\hline Fluorescence microscopy & $\mathrm{HCV}$ & Single copy virus & NA & 215 \\
\hline Fluorescence microscopy & E.coli/salmonella & $\begin{array}{l}10^{1} \mathrm{CFU} \mathrm{ml}^{-1} \text { E. coli } \\
10^{2} \mathrm{CFU} \mathrm{ml}^{-1} \text { Salmonella }\end{array}$ & $10^{1}-10^{8} / 10^{2}-10^{7} \mathrm{CFU} \mathrm{mL} \mathrm{m}^{-1}$ & 215 \\
\hline Fluorescence microscopy with qubit dye & Salmonella typhimurium & $10^{3} \mathrm{CFU} \mathrm{ml}^{-1}$ & NA & 216 \\
\hline Mie scattering & E. coli & $10^{1} \mathrm{CFU} \mathrm{ml}^{-1}$ & $10^{1}-10^{8} \mathrm{CFU} \mathrm{ml} \mathrm{C}^{-1}$ & 217 \\
\hline Bright field microscopy & P. falciparum/sickle cell & $>1.2 \mathrm{um}$ & NA & 218 \\
\hline Fluorescence microscopy & HSV-1 and HSV-2 & $>99 \%$ & NA & 221 \\
\hline Microfluidic LAMP analysis & $\begin{array}{l}\text { E. coli, V. parahaemolyticus, } \\
\text { S. typhimurium }\end{array}$ & $10^{1}$ copies $\mu \mathrm{L}^{-1}$ & NA & 222 \\
\hline LAMP assay & E. canis, $H$. canis & $10^{-6}$ dilution limit & NA & 223 \\
\hline smaRT-LAMP analysis and qPCR & $\begin{array}{l}\text { Salmonella Typhimurium, } \\
\text { S. enteritidis, Escherichia coli, } \\
\text { Yersinia pseudotuberculosis, } \\
\text { Klebsiella pneumoniae, } \\
\text { Pseudomonas aeruginosa, } \\
\text { S. aureus, } \text { S. pneumoniae }\end{array}$ & $\leq 10 \mathrm{CFU} \mathrm{mL}$ & $\begin{array}{l}5 \times 10^{3}-1 \times 10^{5} \mathrm{CFU} \mathrm{ml} \mathrm{m}^{-1} \\
(2-40 \mathrm{CFU} \text { per reaction })\end{array}$ & 224 \\
\hline
\end{tabular}

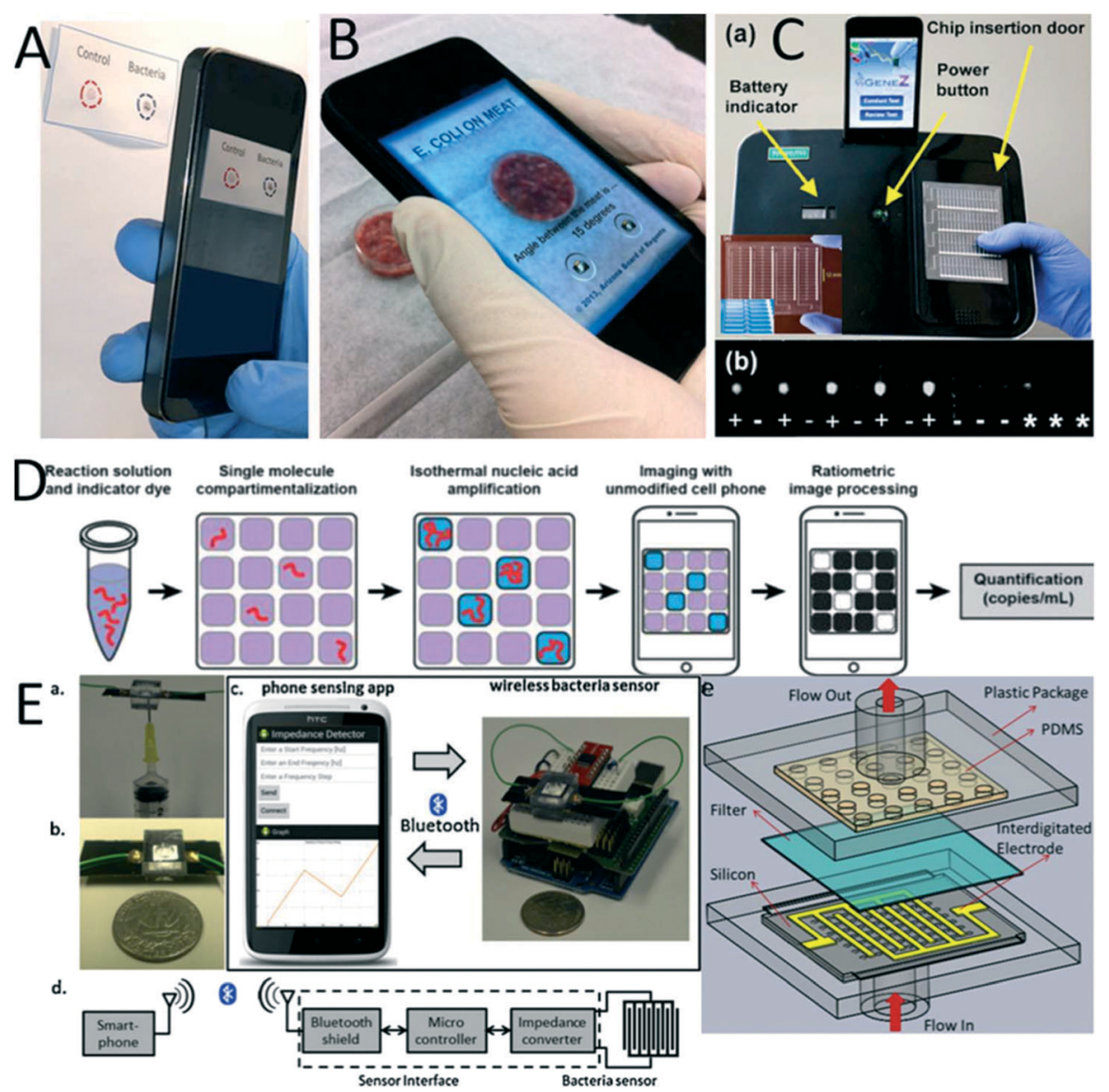

Fig. 5 Smartphone-based POC platforms for pathogen detection. (A) Paper chip for detection of $E$. coli with a gold nanoparticle conjugated recognition element. (B) Detection of $E$. coli in a meat sample utilizing Mie scattering with a smartphone. (C) Microfluidic chip for nucleic acid detection using LAMP and optical sensing modality. (D) SlipChip platform integrated with a cell phone to detect single HCV RNA with no additional lenses. (E) Portable impedance meter for the detection of bacteria. (a and b) Image of a microchip where the sample is injected into the chip using a syringe. (c) A communication sensing platform that transfers signals into the smartphone. (d) Schematic of wireless sensing. (e) Schematic of the microfluidic chip configuration. The sample was injected at the bottom, and bacteria filtered on the top of the interdigitated electrode for EIS detection. Reproduced with permission from ref. 217, 219 and 220. 
compartmentalized in each reservoir of SlipChip. ${ }^{227}$ After amplifying each well, the positive results were recorded and monitored using an unmodified cell phone camera (Fig. 5D and E). In another effort, Berg et al. ${ }^{221}$ developed a 96 well plate ELISA reader using an LED array. The light was then collected using an optical fibre to monitor HIV-1 and HSV-2 viruses with $99.4 \%$ and $99.4 \%$ accuracy, respectively. Electrochemical sensing modality, thus, has been widely integrated with smartphones. These strategies are highly applied in many clinical diagnostic applications and pave a path towards more modernistic and unique POC devices.

\section{Conclusions and future trends}

In recent years research development in POC diagnostic platforms has shown many advantages in their miniaturization process, nanotechnologies involved, genomics and proteomics studied, and microfluidics used. In addition, POC platforms possess simple test procedures, demonstrate fast analysis time, are readily available for everyone, do not require skilled professionals or high-end instruments, are inexpensive, and require a low sample volume and fewer reagents. POC diagnostics can be performed easily in remote areas without any big investments of laboratory facilities. Moreover, integrating nanotechnology and nanomaterials with biosensors has revolutionized diagnostic and therapeutic applications like microbe detection. The application of novel NPs and NMs in biosensors has resulted in an enhanced signal to noise ratio and reduction in time taken for sensing compared to conventional processes; therefore, it bears excellent potential for POC testing devices.

Despite the booming advantages of POC diagnostic devices, there are still a few challenges that need to be addressed. The image-processing applications on biosensing devices like optical sensors imply them to be facile. However, they do not require an additional integrated appliance, which leads to next-generation applications for affordable POC diagnostic devices that can be monitored online. Under further advanced and developed laboratories, researchers use cloud-based biosensing analysis where data does not need to be stored in an external device. Instead it is directly stored in the cloud for easy accessibility. Therefore, on-spot detection with POC analysis can become user-friendly if the diagnostic results are readily available to the general public online.

Techniques like fluorescent detection that requires light excitation sources can be replaced with colorimetric dyes that do not require any light source for fluorescent excitation. Also, electrochemical and electrical sensing modalities can be integrated with smartphones by designing amperometric, voltammetric, and EIS circuits. However, in all these techniques, wire communication and cloud-based analysis are mandatory and therefore limit mobility. Instead, wireless signal analysis can be used which instantaneously records data and reduces data storage problems. Thus, data communication has opened a new paradigm to develop personalized POC monitoring devices to detect pathogens that cause most infectious diseases.

To further improve such biosensing devices that can detect bacteria, fungi, toxins, and viruses from food, water, air, the following points need to be considered:

- More work needs to be done to improve the modified matrix in biosensors that attach to bio-recognition molecules.

- Various conducting surfaces made of polymers and conductive materials must be further analyzed to obtain better outcome signals in POC devices.

- For advanced detection of toxins, more bacterial species need to be explored so that they can act as biorecognition molecules with better accuracy.

- More biosensors need to be explored and developed such they can be used as on-site detection devices.

- The low LOD and wide range of detection limits make biosensors a very appealing technology to detect various pathogens.

- The biosensing prototypes discussed in previous sections are extremely useful and promising to solve many long-term health complications and environmental problems.

- With the increasing demands of market investment in research and development, researchers will lead to a successful path to make POC devices faster, simpler, and cheaper for the benefit of the people and society.

\section{Funding}

Minhaz Uddin Ahmed would like to acknowledge the financial support for the project provided by Brunei Research Council (Grant\# BRC-10) from the Economic and Planning Development, Prime Minister's Office of Negara Brunei Darussalam. Mohammadali Safavieh wishes to thank the National Science Engineering Research Council of Canada for the financial support through NSERC Postdoctoral fellow.

\section{Author contributions}

Sharmili Roy, Fareeha Arshad, Minhaz Uddin Ahmed, and Shimaa Eissa wrote the parts related to nanomaterials and sensing parts. Mohammadali Safavieh and Minhaz Uddin Ahmed wrote the parts related to microfluidics and LOC. Sanaa G. Alattas, Minhaz Uddin Ahmed, and Mohammed Zourob wrote the parts related to the recognition receptors. Minhaz Uddin Ahmed and Mohammed Zourob proofread the review article.

\section{Conflicts of interest}

The authors report no declarations of interest.

\section{References}

1 M. Zarei, Biosens. Bioelectron., 2018, 106, 193-203.

2 M. Pohanka, Int. J. Anal. Chem., 2021, 2021, 1-9. 
3 O. Tokel, U. H. Yildiz, F. Inci, N. G. Durmus, O. O. Ekiz, B. Turker, C. Cetin, S. Rao, K. Sridhar, N. Natarajan, H. Shafiee, A. Dana and U. Demirci, Sci. Rep., 2015, 5(1), 9152.

4 L. Zheng, G. Cai, S. Wang, M. Liao, Y. Li and J. Lin, Biosens. Bioelectron., 2019, 124-125, 143-149.

5 T. Nguyen, V. A. Chidambara, S. Z. Andreasen, M. Golabi, V. N. Huynh, Q. T. Linh, D. D. Bang and A. Wolff, TrAC, Trends Anal. Chem., 2020, 131, 116004.

6 M. Vouga and G. Greub, Clin. Microbiol. Infect., 2016, 22(1), $12-21$.

7 M. Georgieva, A. Leeson-Payne, M. Dumitrascuta, A. Rajnicek, M. Malcangio, W. Huang and J. Neurosci, Methods, 2018, 304, 92-102.

8 K. B. Mullis, Sci. Am., 1990, 262(4), 56-61, 64-5.

9 A. E. Katz, C. A. Olsson, A. J. Raffo, C. Cama, H. Perlman, E. Seaman, K. M. O'Toole, D. McMahon, M. C. Benson and R. Buttyan, Urology, 1994, 43(6), 765-775.

10 J. H. Schefe, K. E. Lehmann, I. R. Buschmann, T. Unger and H. Funke-Kaiser, J. Mol. Med., 2006, 84(11), 901-910.

11 P. G. Lantz, B. Hahn-Hägerdal and P. Rådström, Trends Food Sci. Technol., 1994, 5(12), 384-389.

12 S. Roy and A. Baranwal, Diagnostic Strategies for COVID-19 and Other Coronaviruses, 2020, pp. 135-139.

13 S. Roy and A. Ramadoss, Environmental and Health Management of Novel Coronavirus Disease (COVID-19), 2021, pp. 3-39.

14 M. G. Dastidar and S. Roy, Environmental and Health Management of Novel Coronavirus Disease (COVID-19), 2021, pp. 345-378.

15 N. S. Sampath Kumar, A. D. Chintagunta, S. P. Jeevan Kumar, S. Roy and M. Kumar, 3 Biotech, 2020, 10(12), 527.

16 S. L. Nightingale, J. M. Prasher and S. Simonson, Emerging Infect. Dis., 2007, 13(7), 1046-1051.

17 H. Zhu, H. Zhang, S. Ni, M. Korabečná, L. Yobas and P. Neuzil, TrAC, Trends Anal. Chem., 2020, 130, 115984.

18 J. R. Crowther, ELISA, 2003, vol. 42, pp. 1-218.

19 B. K. Kumar, P. Raghunath, D. Devegowda, V. K. Deekshit, M. N. Venugopal and I. Karunasagar, Int. J. Food Microbiol., 2011, 145(1), 244-249.

20 F. J. Bolton, E. Fritz, S. Poynton and T. Jensen, J. AOAC Int., 2000, 83(2), 299-303.

21 S. Hosseini, P. Vázquez-Villegas, M. Rito-Palomares and S. O. Martinez-Chapa, SpringerBriefs in Applied Sciences and Technology, 2018, pp. 67-115.

22 L. Wu, G. Li, X. Xu, L. Zhu, R. Huang and X. Chen, TrAC, Trends Anal. Chem., 2019, 113, 140-156.

23 M. Severgnini, P. Cremonesi, C. Consolandi, G. De Bellis and B. Castiglioni, Food Bioprocess Technol., 2011, 4, 936-953.

24 N. V. Zaytseva, V. N. Goral, R. A. Montagna and A. J. Baeumner, Lab Chip, 2005, 5(8), 805-811.

25 D. Wang, L. Coscoy, M. Zylberberg, P. C. Avila, H. A. Boushey, D. Ganem and J. L. DeRisi, Proc. Natl. Acad. Sci. U. S. A., 2002, 99(24), 15687-15692.
26 B. Spiess, W. Seifarth, M. Hummel, O. Frank, A. Fabarius, C. Zheng, H. Mörz, R. Hehlmann and D. Buchheidt, J. Clin. Microbiol., 2007, 45(11), 3743-3753.

27 G. J. Vora, C. E. Meador, D. A. Stenger and J. D. Andreadis, Appl. Environ. Microbiol., 2004, 70(5), 3047-3054.

28 S. Roy, S. J. Malode, N. P. Shetti and P. Chandra, Bioelectrochemical Interface Engineering, 2019, pp. 325-342.

29 A. Kumar, S. Roy, A. Srivastava, M. M. Naikwade, B. Purohit, K. Mahato, V. G. M. Naidu and P. Chandra, Nanotechnology in Modern Animal Biotechnology, 2019, pp. 149-161.

30 C. Ziegler and W. Göpel, Curr. Opin. Chem. Biol., 1998, 2(5), 585-591.

31 V. Velusamy, K. Arshak, O. Korostynska, K. Oliwa and C. Adley, Biotechnol. Adv., 2010, 28(2), 232-254.

32 A. G. Gehring and S. I. Tu, Annu. Rev. Anal. Chem., 2011, 4, 151-172.

33 N. P. Shetti, S. J. Malode, S. Roy, P. Chandra, K. R. Reddy and S. Chatterjee, Nanomaterials in Diagnostic Tools and Devices, 2020, pp. 293-329.

34 Y. Shang, J. Sun, Y. Ye, J. Zhang, Y. Zhang and X. Sun, Crit. Rev. Food Sci. Nutr., 2020, 60(2), 201-224.

35 S. Roy, I. A. Rahman, J. H. Santos and M. U. Ahmed, Food Control, 2016, 61, 70-78.

36 S. Roy, M. M. Hossain, M. Safavieh, H. N. Lubis, M. Zourob and M. U. Ahmed, Food Chemistry, Function and Analysis, 2017, pp. 367-392.

37 M. Vincent, Y. Xu and H. Kong, EMBO Rep., 2004, 5(8), 795-800.

38 C. Shi, Q. Liu, C. Ma and W. Zhong, Anal. Chem., 2014, 86(1), 336-339.

39 Y. Zhou, J. Xiao, X. Ma, Q. Wang and Y. Zhang, Appl. Microbiol. Biotechnol., 2018, 102(12), 5299-5308.

40 M. J. Hall, S. D. Wharam, A. Weston, D. L. N. Cardy and W. H. Wilson, BioTechniques, 2002, 32(3), 604-606, 608611.

41 N. F. N. Azam, S. Roy, S. A. Lim and M. Uddin Ahmed, Food Chem., 2018, 248, 29-36.

42 H. Munirah, S. Roy, J. L. Z. Ying, I. A. Rahman and M. U. Ahmed, Sci. Bruneiana, 2016, 15.

43 S. Roy, S. X. Wei, I. A. Rahman and M. U. Ahmed, Malays. J. Microbiol., 2016, 5, 332-338.

44 M. Safavieh, M. K. Kanakasabapathy, F. Tarlan, M. U. Ahmed, M. Zourob, W. Asghar and H. Shafiee, ACS Biomater. Sci. Eng., 2016, 2(3), 278-294.

45 S. Roy, N. F. Mohd-Naim, M. Safavieh and M. U. Ahmed, ACS Sens., 2017, 2(11), 1713-1720.

46 Y. Fu, X. Zhou, X. Duan, C. Liu, J. Huang, T. Zhang, S. Ding and X. Min, Sens. Actuators, B, 2020, 321, 128502.

47 J. W. F. Law, N. S. A. Mutalib, K. G. Chan and L. H. Lee, Front. Microbiol., 2015, 5, 770.

48 M. Di Fabrizio, S. Lupi and A. D'Arco, JPhys Photonics, 2021, 3(3), 032001.

49 I. Banerjee, T. Salih, H. Ramachandraiah, J. Erlandsson, T. Pettersson, A. C. Araújo, M. Karlsson and A. Russom, RSC Adv. , 2017, 7(56), 35048-35054. 
50 K. Kant, M. A. Shahbazi, V. P. Dave, T. A. Ngo, V. A. Chidambara, L. Q. Than, D. D. Bang and A. Wolff, Biotechnol. Adv., 2018, 36(4), 1003-1024.

51 J. Hwang, S. Lee and J. Choo, Nanoscale, 2016, 8(22), 11418-11425.

52 B. Purohit, A. Kumar, K. Mahato, S. Roy and P. Chandra, Nanotechnology in Modern Animal Biotechnology: Concepts and Applications, 2019, pp. 133-147.

53 E. H. Chowdhury and T. Akaike, Biotechnol. Bioeng., 2005, 90(4), 414-421.

54 Y. Alhamoud, D. Yang, S. S. Fiati Kenston, G. Liu, L. Liu, H. Zhou, F. Ahmed and J. Zhao, Biosens. Bioelectron., 2019, 141, 111418.

55 S. Schlafer and R. L. Meyer, J. Microbiol. Methods, 2017, 138, 50-59.

56 J. Wang and S. T. Yau, Anal. Methods, 2014, 4(14), 5387-5391.

57 M. Xu, R. Wang and Y. Li, Talanta, 2016, 148, 200-208.

58 N. Singh, V. Sreenivas, A. Sheoran, S. Sharma, K. B. Gupta, G. K. Khuller and P. K. Mehta, J. Microbiol. Methods, 2016, 120, 56-64.

59 J. Lum, R. Wang, K. Lassiter, B. Srinivasan, D. Abi-Ghanem, L. Berghman, B. Hargis, S. Tung, H. Lu and Y. Li, Biosens. Bioelectron., 2012, 38(1), 67-73.

60 A. Bhimji, A. A. Zaragoza, L. S. Live and S. O. Kelley, Anal. Chem., 2013, 85(14), 6813-6819.

61 M. F. M. Fathil, M. K. Md Arshad, S. C. B. Gopinath, U. Hashim, R. Adzhri, R. M. Ayub, A. R. Ruslinda, M. Nuzaihan, A. H. Azman, M. Zaki and T. H. Tang, Biosens. Bioelectron., 2015, 70, 209-220.

62 K. H. Kwon, S. Y. Hwang, Y. K. Park, J. W. Yoon, S. Kim and J. Hong, J. Food Saf., 2014, 34(3), 249-256.

63 X. He, L. Zhang, P. Liu, L. Liu, H. Deng and J. Huang, Immunol. Res., 2015, 61(3), 281-293.

64 S. K. Pandey, C. R. Suri, M. Chaudhry, R. P. Tiwari and P. Rishi, Mol. BioSyst., 2012, 8(7), 1853-1860.

65 B. Tian, R. S. Bejhed, P. Svedlindh and M. Strömberg, Biosens. Bioelectron., 2016, 77, 32-39.

66 I. H. Cho and J. Irudayaraj, Anal. Bioanal. Chem., 2013, 405(10), 3313-3319.

67 M. Anese, F. Bot, A. Panozzo, G. Mirolo and G. Lippe, Food Chem., 2015, 172, 685-691.

68 P. Bouvrette and J. H. T. Luong, Int. J. Food Microbiol., 1995, 27(2-3), 129-137.

69 G. Zhao, X. Zhan and W. Dou, Anal. Biochem., 2011, 408(1), 53-58.

70 T. Matsushita, N. Shirasaki, Y. Tatsuki and Y. Matsui, Water Res., 2013, 47(15), 5819-5827.

71 A. Thongprachum, P. Khamrin, N. Chaimongkol, R. Malasao, S. Okitsu, M. Mizuguchi, N. Maneekarn and H. Ushijima, J. Med. Virol., 2010, 82(12), 2106-2109.

72 Y. S. Fang, S. Y. Chen, X. J. Huang, L. S. Wang, H. Y. Wang and J. F. Wang, Biosens. Bioelectron., 2014, 53, 238-244.

73 C. L. Morgan, D. J. Newman and C. P. Price, Clin. Chem., 1996, 42(2), 193-209.
74 S. Jain and R. Gulati, Natl. J. Maxillofac. Surg., 2011, 2(1), 33-37.

75 A. Rajkovic, B. El Moualij, Y. Fikri, K. Dierick, W. Zorzi, E. Heinen, A. Uner and M. Uyttendaele, Food Anal. Methods, 2012, 5(3), 319-326.

76 V. A. Petrenko and G. P. Smith, Protein Eng., 2000, 13(8), 589-592.

77 J. Brigati, D. D. Williams, I. B. Sorokulova, V. Nanduri, I. H. Chen, C. L. Turnbough and V. A. Petrenko, Clin. Chem., 2004, 50(10), 1899-1906.

78 A. Hayhurst, S. Happe, R. Mabry, Z. Koch, B. L. Iverson and G. Georgiou, J. Immunol. Methods, 2003, 276(1-2), 185-196.

79 L. J. Sherwood, L. E. Osborn, R. Carrion, J. L. Patterson and A. Hayhurst, J. Infect. Dis., 2007, 196(Suppl 2), S213-S219.

80 E. Goldman and S. Walper, Methods Mol. Biol., 2014, 1108, 201-210.

81 E. R. Goldman, J. L. Liu, R. D. Bernstein, M. D. Swain, S. Q. Mitchell and G. P. Anderson, Sensors, 2009, 9(1), 542-555.

82 T. Ktari, H. Baccar, M. B. Mejri and A. Abdelghani, Int. J. Electrochem., 2012, 2012(8), 421692.

83 S. K. Arya, A. Singh, R. Naidoo, P. Wu, M. T. McDermott and S. Evoy, Analyst, 2011, 136(3), 486-492.

84 N. Tawil, E. Sacher, R. Mandeville and M. Meunier, Biosens. Bioelectron., 2012, 37(1), 24-29.

85 M. Smietana, W. J. Bock, P. Mikulic, A. Ng, R. Chinnappan and M. Zourob, Opt. Express, 2011, 19(9), 7971-7978.

86 S. M. Tripathi, W. J. Bock, P. Mikulic, R. Chinnappan, A. $\mathrm{Ng}$, M. Tolba and M. Zourob, Biosens. Bioelectron., 2012, 35(1), 308-312.

87 A. Mazhorova, A. Markov, A. Ng, R. Chinnappan, O. Skorobogata, M. Zourob and M. Skorobogatiy, Opt. Express, 2012, 20(5), 5344-5355.

88 J. Wang, Biosens. Bioelectron., 2006, 21(10), 1887-1892.

89 T. Neufeld, A. Schwartz-Mittelmann, D. Biran, E. Z. Ron and J. Rishpon, Anal. Chem., 2003, 75(3), 580-585.

90 O. Laczka, C. García-Aljaro, F. J. del Campo, F. X. M. Pascual, J. Mas-Gordi and E. Baldrich, Anal. Chim. Acta, 2010, 677(2), 156-161.

91 M. Yemini, Y. Levi, E. Yagil and J. Rishpon, Bioelectrochemistry, 2007, 70(1), 180-184.

92 A. S. Mittelmann, E. Z. Ron and J. Rishpon, Anal. Chem., 2002, 74(4), 903-907.

93 A. Leung, P. M. Shankar and R. Mutharasan, Sens. Actuators, B, 2007, 125(2), 688-703.

94 A. Shabani, M. Zourob, B. Allain, C. A. Marquette, M. F. Lawrence and R. Mandeville, Anal. Chem., 2008, 80(24), 9475-9482.

95 A. Shabani, C. A. Marquette, R. Mandeville and M. F. Lawrence, Talanta, 2013, 116, 1047-1053.

96 V. Nanduri, I. B. Sorokulova, A. M. Samoylov, A. L. Simonian, V. A. Petrenko and V. Vodyanoy, Biosens. Bioelectron., 2007, 22(6), 986-992.

97 E. V. Olsen, I. B. Sorokulova, V. A. Petrenko, I. H. Chen, J. M. Barbaree and V. J. Vodyanoy, Biosens. Bioelectron., 2006, 21(8), 1434-1442. 
98 R. S. Lakshmanan, R. Guntupalli, J. Hu, V. A. Petrenko, J. M. Barbaree and B. A. Chin, Sens. Actuators, B, 2007, 126(2), 544-550.

99 M. K. Park, J. W. Park, H. C. Wikle and B. A. Chin, Sens. Actuators, B, 2013, 176, 1134-1140.

100 S. Li, Y. Li, H. Chen, S. Horikawa, W. Shen, A. Simonian and B. A. Chin, Biosens. Bioelectron., 2010, 26(4), 1313-1319.

101 S. M. Usman Ali, O. Nur, M. Willander and B. Danielsson, Sens. Actuators, B, 2010, 145(2), 869-874.

102 N. Bhardwaj, S. K. Bhardwaj, J. Mehta, G. C. Mohanta and A. Deep, Anal. Biochem., 2016, 505, 18-25.

103 J. Wan, M. L. Johnson, R. Guntupalli, V. A. Petrenko and B. A. Chin, Sens. Actuators, B, 2007, 127(2), 559-566.

104 L. Fu, S. Li, K. Zhang, I. H. Chen, J. M. Barbaree, A. Zhang and Z. Cheng, IEEE Sens. J., 2011, 11(8), 1684-1691.

105 S. S. Sekhon, S. G. Kim, S. H. Lee, A. Jang, J. Min, J. Y. Ahn and Y. H. Kim, Mol. Cell. Toxicol., 2013, 9(4), 311-317.

106 C. Tuerk and L. Gold, Science, 1990, 249(4968), 505-510.

107 R. Green, A. D. Ellington and J. W. Szostak, Nature, 1990, 347(6291), 406-408.

108 D. O. Demirkol and S. Timur, Int. J. Polym. Mater. Polym. Biomater., 2016, 65(2), 85-90.

109 J. Khang, D. Kim, K. W. Chung and J. H. Lee, Talanta, 2016, 147, 177-183.

110 R. B. Queirós, N. De-Los-Santos-Álvarez, J. P. Noronha and M. G. F. Sales, Sens. Actuators, B, 2013, 181, 766-772.

111 R. B. Queirós, C. Gouveia, J. R. A. Fernandes and P. A. S. Jorge, Biosens. Bioelectron., 2014, 62, 227-233.

112 R. Aimaiti, L. Qin, T. Cao, H. Yang, J. Wang, J. Lu, X. Huang and Z. Hu, Appl. Microbiol. Biotechnol., 2015, 99(21), 9073-9083.

113 F. He, Y. Xiong, J. Liu, F. Tong and D. Yan, Biosens. Bioelectron., 2016, 77, 799-804.

114 X. L. Tang, Y. X. Zhou, S. M. Wu, Q. Pan, B. Xia and X. L. Zhang, J. Infect., 2014, 69(6), 569-580.

115 I. Shiratori, J. Akitomi, D. A. Boltz, K. Horii, M. Furuichi and I. Waga, Biochem. Biophys. Res. Commun., 2014, 443(1), 37-41.

116 M. F. Fatin, A. R. Ruslinda, M. K. Md Arshad, S. Norhafizah, M. A. Farehanim, R. M. Ayub and U. Hashim, IECBES 2014, Conference Proceedings - 2014 IEEE Conference on Biomedical Engineering and Sciences: 'Miri, Where Engineering in Medicine and Biology and Humanity Meet', 2014.

117 A. Rahim Ruslinda, K. Tanabe, S. Ibori, X. Wang and H. Kawarada, Biosens. Bioelectron., 2013, 40(1), 277-282.

118 E. Herrera-Carrillo and B. Berkhout, Adv. Exp. Med. Biol., 2015, 848, 71-95.

119 A. Abbaspour, F. Norouz-Sarvestani, A. Noori and N. Soltani, Biosens. Bioelectron., 2015, 68, 149-155.

120 A. Baumstummler, D. Lehmann, N. Janjic and U. A. Ochsner, Lett. Appl. Microbiol., 2014, 59(4), 422-431.

121 Y. Huang, X. Chen, N. Duan, S. Wu, Z. Wang, X. Wei and Y. Wang, Food Chem., 2015, 166, 623-629.

122 Y. Lian, F. He, H. Wang and F. Tong, Biosens. Bioelectron., 2015, 65, 314-319.
123 J. Shangguan, Y. Li, D. He, X. He, K. Wang, Z. Zou and H. Shi, Analyst, 2015, 140(13), 4489-4497.

124 J. J. Clarkson, S. Dodsworth and M. W. Chase, Plant Syst. Evol., 2017, 303(8), 1001-1012.

125 X. Ma, Y. Jiang, F. Jia, Y. Yu, J. Chen and Z. Wang, J. Microbiol. Methods, 2014, 98, 94-98.

126 S. H. Lee, J. Y. Ahn, K. A. Lee, H. J. Um, S. S. Sekhon, T. Sun Park, J. Min and Y. H. Kim, Biosens. Bioelectron., 2015, 68, 272-280.

127 D. S. Ediriweera, A. Kasturiratne, A. Pathmeswaran, N. K. Gunawardena, B. A. Wijayawickrama, S. F. Jayamanne, G. K. Isbister, A. Dawson, E. Giorgi, P. J. Diggle, D. G. Lalloo and H. J. de Silva, PLoS Neglected Trop. Dis., 2016, 10(7), e0004813.

128 N. Duan, X. Ding, S. Wu, Y. Xia, X. Ma, Z. Wang and J. Chen, J. Microbiol. Methods, 2013, 94(3), 170-174.

129 R. Sharma, V. V. Agrawal, P. Sharma, R. Varshney, R. K. Sinha and B. D. Malhotra, J. Phys.: Conf. Ser., 2012, 358(1), 012001.

130 K. J. Huang, Y. J. Liu, G. W. Shi, X. R. Yang and Y. M. Liu, Sens. Actuators, B, 2014, 201, 579-585.

131 J. Dong, H. Zhao, M. Xu, Q. Maa and S. Ai, Food Chem., 2013, 141(3), 1980-1986.

132 H. Zhou, D. Yang, N. P. Ivleva, N. E. Mircescu, R. Niessner and C. Haisch, Anal. Chem., 2014, 86(3), 1525-1533.

133 V. K. Gasparyan and I. L. Bazukyan, Anal. Chim. Acta, 2013, 766, 83-87.

134 H. C. Wu, Y. L. Huang, S. C. Lai, Y. Y. Huang and M. F. Shaio, Lett. Appl. Microbiol., 2001, 32(5), 321-325.

135 A. Mokhtarzadeh, R. Eivazzadeh-Keihan, P. Pashazadeh, M. Hejazi, N. Gharaatifar, M. Hasanzadeh, B. Baradaran and M. de la Guardia, TrAC, Trends Anal. Chem., 2017, 97, 445-457.

136 I. Tiwari, M. Singh, C. M. Pandey and G. Sumana, RSC Adv., 2015, 5(82), 67115-67124.

137 R. Jijie, K. Kahlouche, A. Barras, N. Yamakawa, J. Bouckaert, T. Gharbi, S. Szunerits and R. Boukherroub, Sens. Actuators, B, 2018, 260, 255-263.

138 Y. Ning, Q. Gao, X. Zhang, K. Wei and L. Chen, J. Biomol. Screening, 2016, 21(8), 851-857.

139 M. H. M. Zaid, C. E. N. Che-Engku-Chik, N. A. Yusof, J. Abdullah, S. S. Othman, R. Issa, M. F. Md Noh and H. Wasoh, Molecules, 2020, 25(15), 3373.

140 S. Shahrokhian and S. Ranjbar, ACS Sustainable Chem. Eng., 2019, 7(15), 12760-12769.

141 H. Safardoust-Hojaghan, M. Salavati-Niasari, O. Amiri and M. Hassanpour, J. Mol. Liq., 2017, 241, 1114-1119.

142 M. H. Mat Zaid, J. Abdullah, N. A. Yusof, Y. Sulaiman, H. Wasoh, M. F. Md Noh and R. Issa, Sens. Actuators, B, 2017, 241, 1024-1034.

143 L. Hao, L. Xue, F. Huang, G. Cai, W. Qi, M. Zhang, Q. Han, Z. Wang and J. Lin, Micromachines, 2020, 11(3), 281.

144 L. Yang and Y. Li, J. Food Prot., 2005, 68(6), 1241-1245.

145 P. L. Guo, M. Tang, S. L. Hong, X. Yu, D. W. Pang and Z. L. Zhang, Biosens. Bioelectron., 2015, 74, 628-636. 
146 D. Wang, F. Lian, S. Yao, Y. Liu, J. Wang, X. Song, L. Ge, Y. Wang, Y. Zhao, J. Zhang, C. Zhao and K. Xu, ACS Omega, 2020, 5(36), 23070-23080.

147 Y. Wang and E. C. Alocilja, J. Biol. Eng., 2015, 9, 16.

148 F. Zheng, P. Wang, Q. Du, Y. Chen and N. Liu, Front. Chem., 2019, 7, 232.

149 N. Mahheidari, J. Rashidiani, H. Kooshki and K. Eskandari, Curr. Nanosci., 2020, 16(5), 793-804.

150 H. Peng and I. A. Chen, ACS Nano, 2019, 13(2), 1244-1252.

151 T. Bu, P. Jia, J. Liu, Y. Liu, X. Sun, M. Zhang, Y. Tian, D. Zhang, J. Wang and L. Wang, Food Chem.: X, 2019, 3, 100052.

152 W. Gao, B. Li, R. Yao, Z. Li, X. Wang, X. Dong, H. Qu, Q. Li, N. Li, H. Chi, B. Zhou and Z. Xia, Anal. Chem., 2017, 89(18), 9836-9842.

153 Z. Fu, X. Zhou and D. Xing, Sens. Actuators, B, 2013, 182, 633-641.

154 H. J. Qi, S. H. Chen, R. Z. Hao, H. Shi, M. L. Zhang and S. Q. Wang, Anal. Methods, 2012, 4, 1178-1181.

155 P. Gill, A. H. Alvandi, H. Abdul-Tehrani and M. Sadeghizadeh, Diagn. Microbiol. Infect. Dis., 2008, 62(2), 119-124.

156 F. Zhu, G. Zhao and W. Dou, Microchim. Acta, 2018, 185(10), 455.

157 Z. Dehghani, T. Nguyen, M. Golabi, M. Hosseini, A. H. Rezayan, J. Mohammadnejad, A. Wolff and A. C. Vinayaka, Food Control, 2021, 121, 107664.

158 Q. Guo, J. J. Han, S. Shan, D. F. Liu, S. S. Wu, Y. H. Xiong and W. H. Lai, Biosens. Bioelectron., 2016, 86, 990-995.

159 D. C. Vanegas, Y. Rong, N. Schwalb, K. D. Hills, C. Gomes and E. S. McLamore, Smart Biomedical and Physiological Sensor Technology XII, 2015, p. 948708.

160 M. Auffan, J. Rose, J. Y. Bottero, G. V. Lowry, J. P. Jolivet and M. R. Wiesner, Nat. Nanotechnol., 2009, 4(10), 634-641.

161 L. M. Bellan, D. Wu and R. S. Langer, Wiley Interdiscip. Rev.: Nanomed. Nanobiotechnol., 2011, 3(3), 229-246.

162 Z. Jiang, B. Feng, J. Xu, T. Qing, P. Zhang and Z. Qing, Biosens. Bioelectron., 2020, 166, 112471.

163 K. Mahato, P. K. Maurya and P. Chandra, 3 Biotech, 2018, 8(3), 149.

164 A. Merkoçi, Biosens. Bioelectron., 2010, 26(4), 1164-1177.

165 D. Ghosh and N. Chattopadhyay, J. Lumin., 2015, 160, 223-232.

166 H. Liu, F. Zhan, F. Liu, M. Zhu, X. Zhou and D. Xing, Biosens. Bioelectron., 2014, 62, 38-46.

167 X. He and N. Ma, Colloids Surf., B, 2014, 124, 118-131.

168 H. M. Xiong, Y. Xu, Q. G. Ren and Y. Y. Xia, J. Am. Chem. Soc., 2008, 130(24), 7522-7523.

169 X. Yang, Y. Dang, J. Lou, H. Shao and X. Jiang, Theranostics, 2018, 8(5), 1449-1457.

170 Y. Ruan, W. Yu, F. Cheng, X. Zhang, T. Rao, Y. Xia and S. Larré, IET Nanobiotechnol., 2011, 5(2), 47.

171 J. D. Smith, G. W. Fisher, A. S. Waggoner and P. G. Campbell, Microvasc. Res., 2007, 73(2), 75-83.

172 R. Zhang, T. Belwal, L. Li, X. Lin, Y. Xu and Z. Luo, Compr. Rev. Food Sci. Food Saf., 2020, 19(3), 1465-1487.
173 Y. Ma, J. Han, M. Wang, X. Chen and S. Jia, J. Materiomics, 2018, 4(2), 108-120.

174 F. Tian, J. Lyu, J. Shi and M. Yang, Biosens. Bioelectron., 2017, 89(Pt 1), 123-135.

175 J. H. Kang, T. Kim, J. Choi, J. Park, Y. S. Kim, M. S. Chang, H. Jung, K. T. Park, S. J. Yang and C. R. Park, Chem. Mater., 2016, 28(3), 756-764.

176 J. H. Jung, D. S. Cheon, F. Liu, K. B. Lee and T. S. Seo, Angew. Chem., Int. Ed., 2010, 49(33), 5708-5711.

177 Y. F. Duan, Y. Ning, Y. Song and L. Deng, Microchim. Acta, 2014, 181, 647-653.

178 G. Vinodha, L. Cindrella and P. D. Shima, Mater. Res. Express, 2019, 6(8), 085548.

179 P. R. Barthasarathy and W. W. A. Wan Salim, Proceedings, 2020, 60(1), 13.

180 A. Pandey, Y. Gurbuz, V. Ozguz, J. H. Niazi and A. Qureshi, Biosens. Bioelectron., 2017, 91, 225-231.

181 M. S. Mannoor, H. Tao, J. D. Clayton, A. Sengupta, D. L. Kaplan, R. R. Naik, N. Verma, F. G. Omenetto and M. C. McAlpine, Nat. Commun., 2012, 3, 763.

182 C. Liu, D. Jiang, G. Xiang, L. Liu, F. Liu and X. Pu, Analyst, 2014, 139(21), 5460-5465.

183 A. M. Fernandes, M. H. Abdalhai, J. Ji, B. W. Xi, J. Xie, J. Sun, R. Noeline, B. H. Lee and X. Sun, Biosens. Bioelectron., 2015, 63, 399-406.

184 C. García-Aljaro, L. N. Cella, D. J. Shirale, M. Park, F. J. Muñoz, M. V. Yates and A. Mulchandani, Biosens. Bioelectron., 2010, 26(4), 1437-1441.

185 S. Solanki, C. M. Pandey, R. K. Gupta and B. D. Malhotra, Biotechnol. J., 2020, 15(5), e1900279.

186 A. Carbonaro, S. K. Mohanty, H. Huang, L. A. Godley and L. L. Sohn, Lab Chip, 2008, 8(9), 1478-1485.

187 D. A. Boehm, P. A. Gottlieb and S. Z. Hua, Sens. Actuators, $B, 2007,126(2), 508-514$.

188 S. Q. Jin, S. M. Guo, P. Zuo and B. C. Ye, Biosens. Bioelectron., 2015, 63, 379-383.

189 L. Cao, G. C. Han, H. Xiao, Z. Chen and C. Fang, Anal. Chim. Acta, 2020, 1096, 34-43.

190 E. L. Fava, T. A. Silva, T. M. do Prado, F. C. de Moraes, R. C. Faria and O. Fatibello-Filho, Talanta, 2019, 203, 280-286.

191 Z. Liu, D. Ye, R. Chen, B. Zhang, X. Zhu, J. Li and Q. Liao, Int. J. Hydrogen Energy, 2018, 43(49), 22467-22473.

192 G. A. Posthuma-Trumpie, J. Korf and A. Van Amerongen, Anal. Bioanal. Chem., 2009, 393(2), 569-582.

193 L. Wang, X. Shen, T. Wang, P. Chen, N. Qi, B. C. Yin and B. C. Ye, Biosens. Bioelectron., 2020, 165, 112364.

194 W. E. Doering, M. E. Piotti, M. J. Natan and R. G. Freeman, Adv. Mater., 2007, 19(20), 3100-3108.

195 Y. Al-Yousif, J. Anderson, C. Chard-Bergstrom and S. Kapil, Clin. Diagn. Lab. Immunol., 2002, 9(3), 723-725.

196 S. Roy, S. X. Wei, J. L. Z. Ying, M. Safavieh and M. U. Ahmed, Biosens. Bioelectron., 2016, 86, 346-352.

197 Z. Yu, M. Yu, Z. Zhang, G. Hong and Q. Xiong, Nanoscale Res. Lett., 2014, 9(1), 343.

198 S. Roy, I. A. Rahman and M. U. Ahmed, Anal. Methods, 2016, 8(11), 2391-2399. 
199 J. H. Jung, B. H. Park, S. J. Oh, G. Choi and T. S. Seo, Lab Chip, 2015, 15(3), 718-725.

200 B. A. Rohrman and R. R. Richards-Kortum, Lab Chip, 2012, 12(17), 3082-3088.

201 D. Lee, Y. T. Kim, J. W. Lee, D. H. Kim and T. S. Seo, Biosens. Bioelectron., 2016, 79, 273-279.

202 M. U. Ahmed, M. M. Hossain, M. Safavieh, Y. L. Wong, I. A. Rahman, M. Zourob and E. Tamiya, Crit. Rev. Biotechnol., 2016, 36(3), 495-505.

203 M. U. Ahmed, S. Nahar, M. Safavieh and M. Zourob, Analyst, 2013, 138(3), 907-915.

204 M. Safavieh, M. U. Ahmed, E. Sokullu, A. Ng and M. Zourob, Analyst, 2013, 139(2), 482-487.

205 M. Safavieh, M. U. Ahmed, A. Ng and M. Zourob, Biosens. Bioelectron., 2014, 58, 101-106.

206 M. Safavieh, M. U. Ahmed and M. Zourob, Proceedings of IEEE Sensors, 2013.

207 R. Chavali, N. S. Kumar Gunda, S. Naicker and S. K. Mitra, Anal. Methods, 2014, 64(1), 6223-6227.

208 M. Tolba, M. U. Ahmed, C. Tlili, F. Eichenseher, M. J. Loessner and M. Zourob, Analyst, 2012, 137(24), 5749-5756.

209 S. A. Lim and M. U. Ahmed, RSC Adv., 2016, 6(3), 24995-25014.

210 M. Safavieh, S. Khetani, V. Kaul, D. R. Kuritzkes and H. Shafiee, Advances in Global Health through Sensing Technologies 2015, 2015, p. 9490.

211 J. Joo, D. Kwon, H. H. Shin, K. H. Park, H. J. Cha and S. Jeon, Sens. Actuators, B, 2013, 188, 1250-1254.

212 J. Su, J. Xu, Y. Chen, Y. Xiang, R. Yuan and Y. Chai, Chem. Commun., 2012, 9(5), 1852-1861.

213 Y. Xiang and Y. Lu, Anal. Chem., 2012, 84(9), 4174-4178.

214 H. Zhang, X. Ma, Y. Liu, N. Duan, S. Wu, Z. Wang and B. Xu, Biosens. Bioelectron., 2015, 74, 872-877.
215 Q. Wei, H. Qi, W. Luo, D. Tseng, S. J. Ki, Z. Wan, Z. Göröcs, L. A. Bentolila, T. T. Wu, R. Sun and A. Ozcan, ACS Nano, 2013(10), 9147-9155.

216 A. M. Nicolini, C. F. Fronczek and J. Y. Yoon, Biosens. Bioelectron., 2015, 67, 560-569.

217 P. S. Liang, T. S. Park and J. Y. Yoon, Sci. Rep., 2014, 4, 5953.

218 D. N. Breslauer, R. N. Maamari, N. A. Switz, W. A. Lam and D. A. Fletcher, PLoS One, 2009, 4(7), e6320.

219 J. Rodriguez-Manzano, M. A. Karymov, S. Begolo, D. A. Selck, D. V. Zhukov, E. Jue and R. F. Ismagilov, ACS Nano, 2016, 10(3), 3102-3113.

220 R. D. Stedtfeld, D. M. Tourlousse, G. Seyrig, T. M. Stedtfeld, M. Kronlein, S. Price, F. Ahmad, E. Gulari, J. M. Tiedje and S. A. Hashsham, Lab Chip, 2012, 12(8), 1454-1462.

221 B. Berg, B. Cortazar, D. Tseng, H. Ozkan, S. Feng, Q. Wei, R. Y. L. Chan, J. Burbano, Q. Farooqui, M. Lewinski, D. Di Carlo, O. B. Garner and A. Ozcan, ACS Nano, 2015, 9(8), 7857-7866.

222 H. Van Nguyen, V. D. Nguyen, F. Liu and T. S. Seo, ACS Omega, 2020, 5(35), 22208-22214.

223 A. Upadhyay, R. M. Waleed, J. Wang, J. Zhao, Q. Guan, C. Liao and Q. Han, Parasitol. Res., 2021, 120(5), 1-11.

224 L. Barnes, D. M. Heithoff, S. P. Mahan, G. N. Fox, A. Zambrano, J. Choe, L. N. Fitzgibbons, J. D. Marth, J. C. Fried, H. T. Soh and M. J. Mahan, EBioMedicine, 2018, 36, 73-82.

225 S. İ. Dönmez, S. H. Needs, H. M. I. Osborn and A. D. Edwards, Sens. Actuators, B, 2020, 323, 128645.

226 H. Shafiee, W. Asghar, F. Inci, M. Yuksekkaya, M. Jahangir, M. H. Zhang, N. G. Durmus, U. A. Gurkan, D. R. Kuritzkes and U. Demirci, Sci. Rep., 2015, 5, 8719.

227 W. Du, L. Li, K. P. Nichols and R. F. Ismagilov, Lab Chip, 2009, 9(16), 2286-2292. 